Est Ag 43 (2008) 5-85

\title{
El Acompañamiento Personal como Relación Interpersonal según Carl Rogers y Martín Buber.
}

\section{Directividad o no Directividad en el Counselling}

\author{
"Nada se conoce plenamente si no se ama plenamente": \\ S. Agustín, Diversis quaest. 83,35,2. \\ "En la posibilidad de ser yo, la vida conserva su aliento \\ y su vitalidad de fuerza que avanza": \\ E. Levinas.
}

\section{INTRODUCCIÓN}

El problema de si en la relación de ayuda se ha de ser muy directivo, muy poco directivo o nada directivo es un debate apasionante. Esta discusión ha estado latente y, a veces, patente en los cursos del Master realizado en el CEHS de Madrid, 2004-2006.

A primera vista parece que lo normal sería proceder de un modo bastante directivo puesto que, la persona que pide ayuda lo hace porque se encuentra con un problema en el que otra persona llamado consejero, asesor, terapeuta, ayudante o con otros términoś, tendría la misión principal de ayudar a solucionar el problema de que se trata y, de otra parte, tenemos a una persona a la que suele designarse con el nombre de aconsejado, asesorado, enfermo, persona ayudada, cliente, consultante o con otros términos que indicarían cierta pasividad.

Sin embargo, como iremos viendo, poco a poco, a lo largo de este trabajo, las cosas no son tan claras como pueden parecer al mero sentido común.

De hecho, a primera vista, es fácil distinguir entre terapias directivas y no directivas pero en una segunda lectura las cosas no son tan claras. 
Porque, las terapias más directivas no presuponen nunca un efecto directo sobre el problema. "Por el contrario, incluso las psicoterapias menos directivas imponen, sin embargo, el marco y dan discretos golpes de timón para modificar el curso del proceso, aunque no siempre de manera voluntaria o consciente"1. Así, podemos verlo en un video grabado por Grinder y Bandler de una escena en la que Rogers, según ellos, señala indirectamente la decisión a tomar.

Como cuenta J. Segura, buen conocedor de Rogers, asistente a un curso de psicoterapia infantil, del método rogeriano, que no quería condicionar para nada a los niños: "Precisamente este era uno de los temas que más polémica levantaba en las tertulias del curso: el terapeuta, ¿influía o no en el paciente?"2. Anthony de Mello, admirador de Rogers, reconocía en su método una especial habilidad para "dirigir-sin-dirigir", nos dice Domínguez Prieto en el Prólogo a la obra sobre terapia personalista antes citada.

Es cierto que, por ejemplo, en referencia a la Educación, a veces, se oye decir contundentemente: Se tolera todo, no se hace nada, se necesita más dureza, y cosas por el estilo. Pero, por otra parte se afirma, con no menor contundencia, que hay que respetar al educando y que nada se consigue que valga la pena por medio de la fuerza y que no basta vencer o imponer sino que hay que convencer...

Para otros, el psicólogo parecería como un profesional a la deriva, y un tanto pasivo, que se movería según el espíritu y el clima de los tiempos, y se adaptaría, en exceso, al cliente que viene a su consulta y al que, al parecer, suele darle la razón, entre otras cosas, porque tampoco hay que perder clientela. Sin embargo, esto no es nada claro ni evidente. De hecho, un número importante de personas abandonan la consulta del psicólogo por desacuerdo con sus propuestas, o porque, sencillamente, no les da lo que ellas quieren. Lo expresan muy bien Carkhuff y W. A. Anthony, en The Skills of Helping: "Contrariamente a lo que la gente popularmente cree, la mayor parte de los asesorados o bien nunca aparecen a la sesiones de ayuda o abandona el proceso prematuramente. O no han estado nunca comprometidos con dicho proceso o abandonan el compromiso"3.

1 N. SinelnikofF, Las Psicoterapias. Inventario crítico, Herder, Barcelona 1999, p. 133.

2 J. Segura, "Carl Rogers", en X. M. Domínguez Prieto, J. Segura Bernal, A. Barahona PlazA, Personalismo terapéutico. Frankl, Rogers, Girard, Fundación E. Mounier, Madrid 2005, p. 86.

3 Cf. M. MARroquín, La relación de ayuda en Robert $R$. Carkhuff, Mensajero, Bilbao $1991^{2}$, p. 323. 
Otros, por su parte, parece que se preguntan: ¿Seguimos en un existencialismo subjetivista trasnochado que no responde, realmente, para nada, a la situación actual de la gente? Hoy se tiene la impresión de que el esquema existencialista de los años 60 y 70 era demasiado permisivo. Es decir, parece que hemos llegado a una situación en que es preciso marcar con claridad los límites y señalar el camino que es preciso, hoy, emprender y recorrer para educar en una personalidad auténtica capaz de asumir, de verdad, sus responsabilidades actuales y necesarias en nuestro mundo.

Y sin embargo, esto tampoco está claro. En primer lugar, ya, en su tiempo, Sartre denunciaba que la educación burguesa avasallaba al individuo, y le privaba de su propia vida hasta dejarle sin identidad, sin capacidad de emociones ni afectos propios hasta convertirlo en pura trasparencia vacía.

Ahora bien, el hombre no tiene por qué vivir así: dominado, dependiente y sometido a los otros. Pues, aunque es cierto que existe el mal y la violencia, que rompe el equilibrio relacional entre el yo y el mundo, la naturaleza humana es "creación amorosa" y "originariamente bondadosa", según la sabiduría más antigua y actual. Por eso, como dice Marina: la conciencia de ser "autores de la propia acción", nos demuestra la capacidad de alterar "la rueda del destino" y ejerce "una influencia definitiva en todo proceso de cambio".

De ahí, que Fromm maldijera a los tiranos, que propalaban la falsa especie de "la pereza innata" del ser humano. Porque cuando "quieren dominar al hombre, su arma ideológica más eficaz será convencerle de que no puede confiar en su propia voluntad y entendimiento"4. El propio menosprecio es el comienzo de la sumisión y de toda desorientación.

Una primera respuesta a todos estos interrogantes, sería: ¿pero es que puede hacerse algo por la persona sin respetar la dignidad de la persona $y$ sin contar con ella ni valorarla? Como ha dicho, contundentemente, Javier Martín Oterino: "El sujeto es el que sabe lo que le pasa. No hay que presuponer nada hasta que no lo diga". O como lo dice Rogers: es el "cliente quien sabe qué es lo que le afecta, hacia dónde dirigirse, cuáles son sus problemas fundamentales y cuáles sus experiencias olvidadas. Comprendí que, a menos que yo necesitara demostrar mi propia inteligencia y mis conocimientos, lo mejor sería confiar en la dirección que el cliente mismo imprime al proceso"5.

Así, abandonó Rogers el enfoque directivo, un tanto agresivo y coercitivo, de la entrevista personal. No lo hizo por motivos filosóficos sino porque

4 J. A. MARINA, El laberinto sentimental, Anagrama, Barcelona $2001^{3}$, pp. 218-9.

5 C. Rogers, El proceso de convertirse en persona, Paidós, Barcelona $1989^{6}$, p. 22. 
tales métodos "nunca pasan de ser sólo superficialmente eficaces". Luego, también se dio cuenta de que eso mismo vale también para todas las relaciones humanas de la vida de cada día. Y, así, se convenció, también, de que "no me resulta beneficioso comportarme como si yo.fuera distinto de lo que soy", y de que la persona es más eficaz cuando puede escucharse con tolerancia y ser ella misma, sin fachadas ni defensas superficiales, con sus imperfecciones y límites, sin pretender "arreglar las cosas" de forma angelical.

Después, también descubrió Rogers el valor y la satisfacción de poder aceptar y tratar de comprender a otras personas tal como son, sintonizando con ellas en profundidad y abriendo canales para que puedan comunicar sus sentimientos y su mundo privado. Por mucho que, a veces, pensemos que lo mejor sería que todos debieran "sentir, juzgar y creer" como yo lo hago, cuando acepto los sentimientos, las actitudes y las creencias vitales del otro le estoy ayudando a ser él mismo y a convertirse en persona.

Finalmente, Rogers nos descubre que él, como toda persona, puede "confiar en su experiencia", recorrer el propio camino sin sentirse "solo o tonto". Que soy yo mismo, el primero que puedo saber si soy honesto, cabal, coherente, falso o hipócrita conmigo mismo. Y que "esa persona soy yo". Así, mi experiencia es mi "máxima autoridad" y "gozo al entrar en armonía en la experiencia". Además, Rogers se da cuenta de que los hechos nunca son hostiles, por contradictorios que parezcan, porque nos acercan a la verdad y a la solución del problema.

En efecto, la relación de ayuda es un juego de insinuaciones, silencios y verdades, más o menos directas o indirectas, para conseguir que la persona ayudada "elabore su propia realidad". De hecho, según J. Martín Oterino, cuando la persona ayudada siente que 'conduce' su proceso, aumenta enormemente su implicación en los acuerdos y decisiones, y crece, por tanto, la probabilidad de un cambio de conducta verdadero y duradero.

Una experiencia muy definitiva, para Rogers, fue que las personas se orientan siempre, fundamentalmente, con un movimiento constructivo, hacia la autorrealización, el crecimiento, la maduración y la socialización, y abandonan, poco a poco, sus mecanismos de defensa. Esto no quiere decir que los seres humanos no seamos, a veces, crueles, regresivos, destructivos o antisociales. Pero, en palabras de Rogers: "La experiencia me ha enseñado que las personas se orientan en una dirección básicamente positiva"6. Se trata de un "impulso hacia la auto-realización" o de "una tendencia direccional progresiva" que es "el factor del que depende toda psicoterapia".

\footnotetext{
6 Ibid., p. 34.
} 
De ahí que, según Rogers, la cuestión definitiva y más importante no es cómo curar o cambiar a una persona, sino que la pregunta que debe hacerse el counsellor es: “¿Cómo puedo crear una relación que esta persona pueda utilizar para su propio desarrollo?". Entonces, según Rogers, es cuando somos capaces de crear una relación auténtica y transparente con una valoración cálida de la otra persona y una sensibilidad para ver al otro y su mundo tal como él lo ve. Y, así, la persona ayudada experimentará aspectos de sí mismo antes reprimidos, logrará una mayor integración personal, será más eficaz, y se volverá más original y expresiva, emprendedora y confiada.

Además, la persona se volverá más comprensiva y aceptará mejor a los demás y podrá enfrentar los problemas de su vida de una manera más fácil y adecuada. Así es cómo se promueve un desarrollo más maduro y apropiado de la personas.

$\mathrm{Y}$, en definitiva, Rogers piensa que "el núcleo de la naturaleza humana es esencialmente positivo", y que en una terapia exitosa "los clientes parecen llegar a sentir verdadero afecto por ellos mismos". Además, cree que ambas hipótesis han sido "confirmadas por mi experiencia". Hay, pues, una tendencia fuerte en los seres humanos hacia su desarrollo y plena actualización que facilita el proceso.

Según Rogers, la verdadera relación de ayuda es aquella en la que se intenta hacer surgir, de una o ambas partes, una mejor apreciación y expresión de "los recursos latentes en el individuo, y un uso más funcional de éstos". Y eso ocurre así porque, como es sabido, por la experiencia familiar: un rechazo activo de los padres facilita la rebeldía, la agresividad y la pelea, mientras que ser afectuosos y respetuosos facilita la autorrealización y la sensación de confianza e independencia.

En este escrito, que he presentado como Proyecto final del Master en Counselling, he querido hacer un estudio sobre el tema de la directividad o la no directividad que considero un tema apasionante y muy discutido. Desde hace bastante tiempo me ha interesado el tema de las Relaciones Humanas y leí algunas cosas sobre él. Pero al llegarme el programa del CEHS, sobre el Master en Counselling, pensé que debía aprovechar la ocasión. Creo que ha sido un gran acierto pues me ha servido también mucho a nivel personal.

En el caso de Rogers la apuesta por la no directividad ha sido un propuesta muy nueva y con una difusión espectacular, aunque también ha tenido críticas y reparos, como veremos más adelante.

Al comenzar este trabajo, pensaba llegar a una posición muy clara sobre el problema, pero, al elaborarlo, he notado que, aunque ciertas acti- 
tudes a evitar son muy claras, luego decidir qué nivel de no directividad es aceptable o el mejor, en cada caso, es bastante más difícil.

De hecho, las principales dificultades que he encontrado al elaborar este trabajo, me han venido del problema de definir, adecuadamente, el tema mismo estudiado. Es decir, el concepto preciso, e incluso la experiencia básica de directividad y no directividad, parece, en principio, bastante clara, pero luego, al ver cómo la entiende y vive cada uno de los autores no es nada fácil de precisar...

No obstante, puedo decir que estoy bastante contento del resultado, y aunque no he encontrado esa postura definitiva que creía se podía establecer con toda claridad al principio, sí he encontrado orientaciones y señalizaciones muy importantes que aparecen recogidas en las conclusiones y a lo largo de este estudio.

Así, este trabajo, después de esta Introducción, tiene una $\mathrm{I}^{\mathrm{a}}$ parte, en la que se exponen las críticas y quejas contra la directividad y sus peligros, que son bastante importantes, frecuentes y no poco conocidas. En la $\mathrm{II}^{\mathrm{a}}$ parte se trata de mostrar que la no directividad no es una dimisión moral, del compromiso ético con el otro, ni una postura anti-evangélica hacia el prójimo, en el caso de los creyentes cristianos.

La III ${ }^{a}$ parte intenta definir un poco más concretamente lo que es la directividad y la no directividad. En la IV ${ }^{\mathrm{a}}$ parte se expone, brevemente, el método de Rogers, se reconocen algunas críticas que ha recibido y se presenta su apuesta por la no directividad.

En la $V^{a}$ parte se expone el método de Carkhuff que da especial importancia al counsellor y a su preparación, así como a algunas técnicas o variables no aceptadas por Rogers, como es el caso de la confrontación, que suponen una modificación bastante importante del método no directivo de Rogers. Finalmente, en la Conclusión se resumen los hallazgos más señalados que he recogido en el estudio y el tratamiento del tema.

Quiero agradecer al CEHS, a las Profesoras y Profesores de este Master en Counselling, patrocinado por la Universidad R. Lulio de Barcelona, por lo mucho que nos han enseñado profesionalmente, y por el buen ambiente que nos han procurado siempre. En este último apartado es preciso nombrar también a las Compañeras y Compañeros de curso, y demás Personal del Centro que nos han hecho todo más fácil y agradable.

Pero especialmente quiero dar las gracias al profesor José Carlos Bermejo que me ha orientado tanto al indicarme el camino para recoger los materiales básicos del mismo como al ofrecerme, también en sus cursos y en sus libros, algunas líneas fundamentales del tratamiento del tema, y ha supervisado la redacción de este trabajo. 


\section{ADVERTENCIAS CONTRA LA DIRECTIVIDAD Y PRIMERAS APROXIMACIONES A LA NO DIRECTIVIDAD}

Cuando hablamos de directividad o de no directividad, nos referimos a dos maneras bien diferentes de practicar la relación de ayuda o el consejo psicológico. Las críticas a la directividad, en diversos ambientes, han sido siempre muy notables y abundantes, por eso comenzamos por constatar esas advertencias contra la directividad, para dar cuenta de cómo algunos autores se acercan a la no directividad.

Según las teorías que parecen más certeras sobre el counselling, es necesario respetar y promover el valor de la persona, su conocimiento y convencimiento autónomo como un elemento decisivo en la relación de ayuda, porque el counselling es un proceso de apoyo a la persona, y no de suplencia ni de suplantación de la misma. En otro caso, el acompañamiento personal puede llevar a propiciar una sumisión inhumana e inauténtica que invita a la rebeldía más que a la verdadera objetividad o correcta obediencia?.

Como lo dice Giordani: No se puede sucumbir a la tentación de marchar por caminos errados como puede ser el del directivismo, asumiendo la iniciativa de exponer un plan de acción y de iniciar los pasos a dar, o el otro del laxismo, dejando todo a la elección de la persona y renunciando a valorar la propuestas y a "verificar el camino recorrido".

Este directivismo cae en una serie de trampas importantes que pueden resumirse en el egocentrismo, la embriaguez del poder sobre otra persona, la excesiva satisfacción por el aprecio y la confianza recibida, la curiosidad por la vida ajena y unas relaciones confusas, y la proyección de los propios problemas en el proceso de acompañamiento que lo dañará gravemente todo.

Todas esas actitudes conducen inevitablemente a sistemas de relación muy directivos, que en nada ayudan a la persona, como pueden ser: el juicio moralizante, la respuesta interpretativa, el mostrar apoyo-consuelo porque sí, hacer preguntas inquisidoras, o a tratar de solucionar, rápidamente, los problemas sin contar con la persona ${ }^{8}$.

La tendencia a ser directivos, autoritarios y protectores, está muy arraigada aún en nuestra cultura. "Un análisis diferencial entre diversos grupos

\footnotetext{
${ }^{7}$ B. GIORDANI, Encuentro de ayuda espiritual. Adaptación del método de R. R. Carkhuff, Sociedad de Educación Atenas, Madrid 1985, p. 81.

8 J. C. BeRMEJO, Apuntes de relación de ayuda, Sal Terrae, Madrid $1998^{6}$, pp. 47-8 .
} 
ha puesto de manifiesto un hecho particularmente interesante: en el clero, la tendencia al directivismo resulta mucho más acentuada que en otros grupos humanos"9. Y esta orientación directiva no solamente se ejerce con prohibiciones e imposiciones sino también con exhortaciones y consejos agobiantes, con intentos excesivos de persuadir en una determinada dirección, con explicaciones e interpretaciones fáciles y apresuradas e incluso con sugerencias y sugestiones persistentes.

Así, la necesaria "aceptación incondicional" y la "consideración positiva de la persona", tan importantes y propias del acompañamiento personal, con frecuencia, se ven bloqueadas, "especialmente en el mundo eclesiástico" por una educación moralizante y un "mal entendido sentido de responsabilidad" que lleva a actuar con esquemas rígidos, juzgar la conducta ajena de forma apresurada, proponer soluciones rápidas e imponer esquemas éticos sin dejar espacio al debate ni a una "libre confrontación de ideas". Pero, sin la aceptación incondicional y el respeto debido a la persona, el acompañamiento deja de serlo y se queda en pura y "simple instrucción".

Con frecuencia, las posturas directivas vienen propiciadas por: "el deseo de lograr rápidamente un resultado", la convicción de poder dar una explicación segura al problema, el "celo" de dar el máximo en sagacidad y en frutos de experiencia, la conciencia excesiva del papel de "director" espiritual, y, en algunas ocasiones, la petición explícita e insistente que muchas personas hacen para recibir un "consejo".

También la actitud egocéntrica es un socio muy relevante de las posturas directivas. Esta actitud egocéntrica se muestra en que el consejero se presta más atención a sí mismo, a sus pensamientos y reacciones que a los del acompañado, y se centra más en sí mismo que en la persona ayudada.

Las causas más comunes de la actitud egocéntrica son: la preocupación excesiva por el éxito y la propia imagen, la falta de interés por la persona acompañada, la ansiedad ante los problemas que se presentan, la inseguridad en el coloquio y las preocupación excesiva por responder, ya, a lo que expone la persona.

Se puede decir que a la persona egocéntrica le falta amor verdadero y, sobre todo, amor incondicional, fraternal, generoso y gratuito. Por eso, cae, fácilmente, en el paternalismo o el maternalismo al ejercer la relación de ayuda. El amor gratuito y generoso es el que facilita la consideración positiva y la aceptación incondicional de la persona, crea confianza y diálogo abierto, y permite ahondar en el conocimiento del otro y sus propios recursos.

\footnotetext{
${ }^{9}$ B. GIORDANI, op. cit., p. 110.
} 
La actitud directiva se puede expresar de muchas maneras, pero algunas de ellas son: orientar la conversación a donde quiere el acompañante y no hacia donde pide el acompañado, expresar, en seguida, el propio parecer sobre el problema, de modo que condicione las valoraciones que debe hacer la persona acompañada, desviar o bloquear un tema que disgusta o crea dificultades o ansiedad al acompañante, y, también, la tendencia, constante, a juzgar lo expuesto por el acompañado y calificarlo de bueno o malo, hacer demasiadas preguntas, y orientar a la persona acompañada hacia una meta preconcebida, por el terapeuta, con falta de confianza en los recursos de la persona.

En especial, deben considerarse intervenciones directivas, que el asesor proponga a la persona sistemas ideológicos, orientaciones afectivas, relaciones sociales y sentimientos religiosos o morales que el asesor considera como los únicos válidos. Lo mismo ha de decirse cuando el asesor minimiza lo que el aconsejado expone y presenta como grave o amenazante o cerrarse en su propio mundo y pretender integrar lo expuesto por el asesorado en un esquema u orientación propia, solamente del asesor y no del asesorado, y lo mismo ha de decirse cuando se proyectan en la persona ayudada los propios principios, miedos y problemas.

Todas estas posturas son muy malos compañeros de viaje para conseguir un ambiente distendido en el que la persona acompañada se sienta animada a hablar y explorar, tranquilamente, su vida, a hacer un análisis objetivo de sus problemas y a propiciar una empatía adecuada con la persona acompañada que lleve a su integración y a iniciar propuestas de cambio y metas nuevas de esperanza.

Para superar el sentido directivo hay que propiciar, en el asesor, una actitud hetero-céntrica que le ayude a no preocuparse más de sí mismo o de su imagen que de la persona ayudada, a cultivar la apertura mental y la empatía con las personas, a desarrollar la confianza en sí mismo y en los demás, y vivir, con la libertad interior y serenidad, los distintos problemas que nos presenta la vida y las personas a las que intentamos ayudar. Además, conviene desarrollar la disposición a ayudar, el respeto a las experiencias de los otros, la creatividad, y la capacidad de comunicar los valores y posiciones personales cuando sea necesario.

Por otra parte, es preciso tener muy en cuenta la reflexión que hace Rogers cuando afirma que el único aprendizaje que puede influir de forma significativa en la conducta de una persona "es el que el individuo descubre $e$ incorpora por sí mismo". Mientras que los aprendizajes heterónomos, introducidos como desde fuera, tienen muy poca influencia en la conducta de las personas y son como edificios sobre arena. 
Por tanto, ya se trate de enseñar o de aprender es necesario abandonar las propias defensas y dejarse envolver por la experiencia e intentar "comprender lo que la experiencia de la otra persona significa para ella". Pues como dice Quintiliano: "En casi todas las cosas, vale más la experiencia que las normas"(Institutionis Oratoriae 2,5,15). Entonces comienza un cambio significativo y eficaz que se caracteriza porque la persona comienza a verse de otra manera, se acepta a sí mismo y sus sentimientos, más plenamente, siente mayor confianza en sí misma y en sus propias orientaciones, se vuelve más parecida a lo que quisiera ser, se hace más flexible y menos rígida, con objetivos más realistas, se comporta de una forma más madura, sus conductas inadaptadas cambian, se vuelve más capaz de aceptar a los demás, de darse más cuenta de lo que pasa, y su personalidad cambia "en un sentido constructivo".

Ahora bien, según Rogers, este cambio surge de la misma persona ante la dificultad para afrontar a vida. Por tanto, no es directivo ni procede del impulso del ayudante ni de su motivación ni del sujeto ayudado. "Digamos que la motivación para el aprendizaje y el cambio surgen de la tendencia autor-realizadora de la vida misma, de esa inclinación del organismo a fluir en todas las direcciones de desarrollo potencial, en la medida en que estas experiencias sean enriquecedoras"10.

Rogers y los counsellors no directivos tienen una gran confianza en la persona y sus capacidades, pues es su tendencia auto-realizadora la que primero desea "aprender, crecer, descubrir y crear". Hay una tendencia fuerte en los seres humanos hacia su desarrollo y plena actualización que facilita el proceso. Pero, si desconfiamos de los seres humanos no les ayudaremos a desarrollar sus potencialidades ni podremos ofrecerles nuestro apoyo a "sus propias maneras de aprender".

Así, es muy cierto que, el counselor colabora mejor al proceso positivo de la persona ayudada, como veremos más adelante, cuando es una persona coherente, unificada e integrada, acepta incondicionalmente al cliente y tiene con él una buena sintonía empática, de modo que comprende perfectamente los sentimientos de la persona ayudada, se adapta a su situación y comparte sus sentimientos. Y esta actitud es más importante que su capacidad técnica aunque ésta no sea nada desdeñable.

Esta actitud de aprendizaje o acompañamiento "no dirigido" se caracteriza por estar centrada en la atención a la persona, antes de cualquier otra cosa, e intentar ayudar, por encima de todo, $y$, según una conocida expre-

10 C. Rogers, op. cit., p. 251. 
sión de J. Dewey, a la "reconstrucción de la experiencia", dirigida por el amor, de los puntos de vista, actitudes, valores, emociones y conducta de la persona ayudada.

Entonces, la persona se encuentra más directamente y más satisfecha consigo misma, expresa más libremente sus sentimientos, recupera confianza en sí misma y en los demás y la vida se vive desde una base más real, la comunicación se hace más genuina y auténtica en la vida normal, expresando los propios sentimientos más auténticos, positivos o negativos, y, así, se evita que "fermenten" o se envenenen.

Así, cada persona vive su vida desde su propia individualidad e intimidad, pudiendo serse ella misma, andar su propio camino, sin dejarse agobiar por la realidad exterior, ni por los juicios ajenos que provocan la incomunicación y la represión. Entonces uno comprende, también, mejor a los demás, se pone, realmente, en su lugar, siendo "más plena y profundamente él mismo". Es más, el conocimiento íntimo de cómo la persona se recrea y "se remodela a sí misma en la relación terapéutica infunde confianza en el potencial creativo de todos los individuos"11.

Según Rogers, el móvil de la creatividad no se debe buscar ni en la realidad externa ni en el apoyo terapéutico del counsellor, sino que "la fuerza curativa más profunda" se encuentra en: "la tendencia del hombre a realizarse, a llegar a ser sus potencialidades". Es decir, en el impulso del ser humano a crecer, desarrollarse, expandirse, madurar, y en el esfuerzo constante por ser él mismo en relación y en lucha con su medio.

Esta capacidad creativa supone apertura a la experiencia, confianza en las propia capacidad reconstructiva para poner en juego la propia libertad con todas sus potencialidades. También supone desarrollar al máximo la seguridad y confianza en sí mismo que proviene de una aceptación incondicional de la persona, sin dejarse intimidar ni por los juicios ajenos ni por la evaluación externa.

A este crecimiento de la confianza en sí mismo colabora decididamente la comprensión empática, que eleva al máximo la seguridad psicológica, por la aceptación incondicional del otro, y ayuda a comprenderlo desde dentro, desde "su propio punto de vista" y desde su intimidad, "viéndolo tal como él lo ve", para poder aceptarlo sin juicios ni prejuicios. Entonces, se pone en libertad el ser más auténtico de la persona para que pueda expresarse en toda su riqueza.

11 Ibid., p. 303. 
Así, es posible cultivar la libertad psicológica que, por la aceptación incondicional, según Rogers, deja a la persona una rica y abundante "libertad de pensar, sentir y ser lo que guarda en lo más profundo de sí mismo", fomenta la apertura y estimula la creatividad y la responsabilidad de modo que la persona llegue a una auténtica auto-directividad. Para Rogers, esa experiencia de llegar a ser una persona "más autónoma, más espontánea y más confiada", es "la experiencia de la libertad de ser uno mismo".

Finalmente, quizá sea bueno recordar, que en 1969, después de constatar las dificultades para aceptar un diálogo pastoral católico no directivo, descritas por Godin y Hostie, menos reticentes, o por C. A. Curran, más favorable al mismo, Yves Saint-Arnaud, hace una investigación para establecer las condiciones fundamentales de ese diálogo "que se inspire en los principios de la llamada psicología no directiva".

Esas condiciones necesarias a esa relación de ayuda no directiva serían:

1. El consejero se desprende "de las funciones que exigen de su parte actividades de estructuración"12. 2. El consejero se adapta al aconsejado "sin introducir otros objetivos que los del consultante". 3. Además, en esa relación sólo el aconsejado es el experto en los comportamientos y actitudes que él debe adoptar "aquí y ahora". 4. El consejero privilegia las funciones de facilitación "únicamente a través de actividades de información". 5. Además: "En el ejercicio de la función de evaluación, el consultante es el único juez". 6. Finalmente, en la función de re-orientación, el consejero no toma la iniciativa, acompaña al consultante a "determinar sus propios valores" y procesos.

Curran, que es muy favorable a la no directividad, transmite la impresión de un consultante, en pastoral, ante la aceptación incondicional: "Mire, ahora alcanzo a comprender por primera vez cómo Dios puede realmente amarme". Lo mismo dicen J. Laplace y L. Beirnaert, al afirmar que no basta hablar del amor de Dios sino que es necesario amar para trasmitirlo. Así, la persona: "Sabrá entonces de qué le habláis". Por eso, algunos insisten, citando a Rogers y Kinget, en que la relación no directiva no es tanto una manera de obrar como "una manera de ser".

12 Y. SAINT-ARNAUD, La consulta pastoral de orientación rogeriana, Herder, Barcelona 1972, p. 42. Max Pagès, autor de varios escritos sobre la no-directividad, distingue muy bien entre "actividades de información", a petición del aconsejado, compatibles con la no directividad, y "actividades de estructuración", que señalarían al aconsejado objetivos, valores, medios concretos de solución, que son incompatibles con el método no directivo: Y. SAINTARNAUD, op. cit., pp. 34-35. 
R. Elliot, al ver las tensiones de los pastoralistas con el método de Rogers, dice que él invita a: $1^{\circ}$. "Arriesgarme yo mismo a sumergirme con amor en la experiencia viva del otro". 2 . "Respetar el derecho y la responsabilidad de la otra persona en la dirección de su propia vida". $3^{\circ}$. "Confiar en las fuentes de curación y de crecimiento que escapan a mi control y al del parroquiano"13.

Varias autores como Plé, Gleason, Cavanagh y Clinebell consideran que el método no directivo es incompatible con el sentido profundo del ministerio católico. Pero Hiltner, protestante, y Curran, católico, creen lo contrario. Wilson piensa que el método no directivo refleja muy bien las "actitudes cristianas tradicionales". Además, Thurian cree que es más eficaz que otros métodos. Y Murphy aprecia la ayuda de la no directividad para poder desarrollar, realmente, un "amor transformante".

Después de un estudio de la práctica pastoral entre los sacerdotes de la diócesis de Montreal, Y. Saint-Arnaud llega a la conclusión de que, "de suyo, desde el punto de vista psicológico, no se advierte ninguna incompatibilidad entre las actitudes básicas de la aproximación rogeriana y el ejercicio de las funciones del diálogo pastoral".

Pero eso no quiere decir que el modelo no directivo haya sido ya aceptado. Al contrario siguió suscitando muchas reticencias. Algunos consideraban "paralizante el método no directivo", otros no parecen renunciar a diferir, en lo posible, las "actividades de estructuración" para dejar expresarse a la persona, e insisten en la importancia de la relación o interpersonal y las actividades de facilitación. Bastantes aceptan una cierta influencia rogeriana pero sin "orientarse hacia un modelo centrado en el consultante". Con palabras de K. Lewin, se puede decir que algo se está moviendo y deshelando...

Mientras tanto, unos hablan de la terapia centrada en el orientador o autoritaria, y otros de la centrada en el orientado o democrática, auto-directiva o no directiva.

13 Y. SAINT-ARNAUD, op. cit., p. 64. 


\section{LA NO-DIRECTIVIDAD, SU FILOSOFIA DEL AMOR Y LA EX- PERIENCIA AGUSTINIANA}

Como ya hemos podido ver, la no directividad, no es sino la consecuencia de respetar la dignidad y los valores de la persona en el counselling, sin moralizar, ni culpabilizar en exceso, ni solucionar los problemas con olvido de la persona a la que queremos ayudar. Se trata de afirmar el valor de la persona y sus posibilidades por medio del amor. No estamos, por tanto, ante ninguna dimisión ética ni nada por el estilo sino ante el recorrido de un camino marcado por el amor.

A pesar de todo eso, algunos asesores se preguntan con preocupación: "¿No disimulará la no directividad un profundo laxismo por detrás de un tinglado de "teorías" psicológicas?" 14. Vamos a ver con más detalle esta cuestión.

Algunos creyentes, que intervienen en relaciones de ayuda, sienten un cierto temor a que la no directividad se salte algunas exigencias evangélicas. Tampoco faltan los que, precipitadamente, ven en los diálogos de Jesús, con la Samaritana o con Nicodemo, "una actitud no directiva". Pero no hay que ir demasiado de prisa.

Es cierto que la Buena Nueva del cristianismo permite afirmar que el mal y la alienación humana no son un destino inevitable y que cada uno puede "reconstruir su campo relacional" con Dios y con el prójimo "como infinitamente digno de ser respetado". Es, igualmente cierto que un optimismo ingenuo tampoco nos conduce a ninguna parte.

Pero, también es importante confiar en el ser humano. Como lo dice Rogers: "La naturaleza fundamental del ser humano, cuando funciona libremente, es constructiva y digna de confianza (...) No hemos de preguntarnos quién controlará los instintos de agresividad (del individuo), ya que, a medida que se vaya haciendo más abierto a todos sus instintos, su necesidad de ser amado y su tendencia a dar afecto a los demás serán tan fuertes como los instintos que le impulsan a golpear y a robar".

Así que el cristianismo nos libera de un optimismo ingenuo, pero también nos asegura que podemos orientar positivamente nuestras relaciones con los demás y con nuestro mundo. Ahora bien, esta será "una dura batalla contra las fuerzas egocéntricas" que nos enseña a descentrarnos a nosotros mismos para ponernos en el lugar del otro, reconocer su dignidad, y a

\footnotetext{
14 X. Thévenot, "La ayuda no directiva: ¿una dimisión ética?", en X. ThÉvenot, Pautas éticas para un mundo nuevo, Verbo Divino, Estella 1988, p. 151.
} 
ser humildes, para no creernos liberadores de nadie, sino adoptar una "actitud de no-omnipotencia que intenta establecerse en toda relación no directiva digna de tal nombre"15.

Además, también hemos de ser auténticos, para no atribuir a los demás nuestras propias limitaciones. Pues es propio de las personas maduras reconocer sus condicionamientos así como la propia tendencia a condicionar.

También podemos tener dudas sobre si nuestro deber profético de denuncia no queda abortado por nuestro silencio en "una relación centrada sobre el interlocutor". Ahora bien, esa capacidad de denuncia profética ha de ser modulada por el amor. Así lo vemos en Jesús, que es muy duro con los fariseos pero también muy comprensivo con los pecadores, y, así, abre sus personas a "un porvenir nuevo".

Y es que todos los diálogos de Jesús están informados por el amor (la ágape). Toda denuncia profética ha de ser "expresión de ese amor" que es paciente, no lleva cuenta del mal sino que lo excusa todo, lo cree todo, lo espera todo y lo soporta todo (1Cor $13,4-7)$. Porque si nos falta el amor no somos nada, y toda relación de ayuda deber ser "la expresión de una relación conforme con la ágape".

En la relación de ayuda la persona busca reconstruir sus evidencias interiores para salir de sus problemas y su angustia de vivir. Es un proceso de humanización en relación con consigo mismo y con los demás, y es una búsqueda y una voluntad de apertura que está presente en toda relación de ayuda.

Pues, a veces la persona tiene la impresión de que ha quedado enredada y encerrada, en sus convicciones morales por un duro super-yo, en una mala idealización que le ha llevado a decepciones continuas, a falsas culpabilidades e incluso al auto-desprecio. $\mathrm{O}$, por el contrario, se encuentra ante un "vacío normativo" que le conduce a la falta de sentido y a la agresividad contra todo.

Así que, los asesores tenemos muchas cuentas que arreglar, con nuestro inconsciente arcaico, tal como aparece en las experiencias de transferencia que todo ser humano experimenta. Por eso, no basta callarse para evitar que la persona se sienta olvidada, con una "permisividad perversa" del asesor que puede sonar también a una actitud un tanto sádica, y que deja "voluntariamente a la persona en su propia angustia".

De ahí que, en casos concretos, no estará de más "atreverse a recordar ciertas exigencias éticas y a solicitar la responsabilidad del sujeto". Pero

15 Ibid., p. 156. 
esta práctica necesita de algunas condiciones para que no lleve a la repetición de reproches alienantes o a una reactivación de los "temores infantiles arcaicos" de la persona que falsearán la verdad del deseo y la conducirán a actitudes regresivas que agravarán "su malestar interior y hasta su inadaptación social".

Para evitar todo eso, el asesor necesita conocerse a sí mismo, aceptarse, con sus contradicciones, tener claras sus motivaciones para ayudar a los otros, dejarse interrogar por la experiencia de su interlocutor, darse cuenta de las transferencias y contra-transferencias que están en juego, ver con calma las ansiedades y deseos que provoca la relación de ayuda, reconocer el poder que representa la interpelación ética, juzgar con libertad su propia formación moral, y, sobre todo, "procurar tener una empatía real".

Todos estos procesos suponen una ascesis muy profunda, una gran voluntad de verdad, "un descentramiento de sí mismo para dar sitio al otro", que se fundamentan en un gran sentido humano y un fuerte espíritu evangélico, lo que demuestra que la verdadera no-directividad está muy lejos de ser "una dimisión ética". Pues, lo que, en definitiva, se le pide al que ayuda no es, simplemente, tener unas buenas técnicas, "por muy preciosas que sean, sino una verdadera forma de ser que sea una realización de la ágape".

Así pues, el asesor necesita tener paciencia, "poner su gozo en la verdad"(1Cor 13,6), y actuar con madurez, para abrir un porvenir auténtico a la persona ayudada. Porque sólo cuando una persona experimenta que "es infinitamente digna de ser respetada" siente a su vez la necesidad de respetar a su prójimo. "Es la experiencia del amor la que provoca al amor"16. Esto vale para la vida individual y personal pero también para el compromiso social de transformar el mundo. Pues, como dice un lema de compromiso solidario: "Si quieres cambiar el mundo, comienza por cambiarte a ti mismo".

Y esto es exactamente así, porque, como dice Rogers, "nada (en la vida humana) está congelado", y, por eso, el fin de toda relación de ayuda, habi-

16 Ibid., p. 164. O como lo dice Rogers, el counselling de orientación autodirectiva: "Supone un amor por el cliente como es, suponiendo que consideramos la palabra amor como equivalente al término teológico 'agapé' y no con su significación usual romántica y posesiva. No me refiero a un sentimiento paternalista, ni sentimental, ni superficialmente social o agradable. Respeta a la otra persona como un individuo distinto, y no lo posee. Es una clase de inclinación que tiene fuerza, pero no es exigente. Nosotros la hemos puesto el nombre de consideración positiva": C. RoGERs, The Interpersonal Relationship: The Core of Guidance, Harvard Educational Review, 1962, 32,420, trad. M. MARRoQuín, o.c. 52. 
litadora, conducida por un amor autentico y no directiva, consiste, precisamente, en:

"Desatar los nudos que bloquean la voluntad, cicatrizar las discordias, quitar el peso del pasado, permitiendo que cada uno reformule y reinicie desde el principio la propia vida: ésta es -también- la tarea del amor (...) Lo ya acontecido que, en su irreversibilidad, continúa oprimiéndonos y haciéndonos infelices, no se opone ya a la fe en la posibilidad de re-inicios repetidos. De acuerdo con la buena nueva, para la que 'pasó lo viejo' y 'todo es nuevo' (2 Cor 5,17), ha sido derrotada la antigua figura del destino"17.

Así, el sufrimiento y el pasado encuentran su rescate, y se impide que el dolor se petrifique en rencor o remordimiento. Ahora bien, el amor no elimina el pasado ni lo olvida pero reduce y rectifica su presión paralizadora y deformante. Como lo dice Bodei: "La fuerza curativa del amor -al fluidificar el pasado viscoso, represado o endurecido y reconvertirlo en fresca energía disponible- condona las culpas y las penas que podían parecer inexpiables. Reinicia así, al menos provisionalmente, la vida: se recosen sus jirones, pierde ponzoña la hostilidad, se aplaca la angustia".

De esta forma, se resucita el pasado muerto y se integra en la construcción de la propia identidad, es la cura sui, le sousi de soi de Foucault que hace real el ego absconditus y alimenta el yo deseado. Según Conn, G. Egan y otros, los cambios hacia este yo deseado, por la auto-superación y la autotrascendencia, conducen inevitablemente:

1.- A una nueva autoconciencia, 2.- a una mayor libertad y responsabilidad, 3.- a un nuevo compromiso, 4.- a vivir desde una elección y decisión propia, 5.- a descubrir la propia identidad y unas relaciones interpersonales significativas, 6.- a buscar nuevo sentido a la vida con nuevos valores, propósitos y metas, 7.- al respeto auténtico a las personas, 8.- a la actualización del crecimiento interior para ser una persona auténtica, 9.- a una lucha esforzada para un continuo crecimiento en madurez, dirección interior propia y relación autónoma, 10.- y, en definitiva, a la auto-creación ${ }^{18}$.

Como es hoy bien sabido, el hombre no es sólo animal racional sino también "animal deseante", dejarlo en la pura racionalidad sería mutilarlo. La historia humana es realidad y utopía, presente y proyecto. "Este modelo niega que la conciencia esté aislada respecto del mundo; la invita, por el

17 R. BoDEI, Ordo amoris. Conflictos terrenos y felicidad celeste, Cuatro, Valladolid 1998, p. 9.

18 W. E. ConN, The desiring Self. Rooting pastoral counselling and spiritual direction in self-transcendence. Paulist Press, New Jersey 1998, p. 153: Appendix: Self-Transcendance in Counseling". 
contrario, a alejarse de su embalse espiritual, a perder su rigidez y a fluidificarse, arrojándose a la corriente tonificante de la 'fuerza de las cosas', para descubrir su propio equilibrio a través de los conflictos y los ajustes continuos, a aclimatarse, en fin, a sus contradicciones", dice Bodei. Este es el proceso integrador del hombre y su historia.

San Agustín tiene el mérito de haber planteado el problema del sondeo integrador del abismo humano, "por el método del interrogante indagador, por el quaerere más que por el simple y protervo afirmare" (Conf. X,17,22). Así, para el santo: "Pecar no significa sino demostrarse indisponibles para la renovación, autoexcluirse de los dolores de parto a que todos los seres se someten en su esfuerzo por renacer rescatados (Rom 8,22-23)". De hecho, nuestra vida no pertenece ni al fatalismo estoico ni a la libertad humana, demasiado humana, vanamente creída e idealizada.

De ahí que, a cada uno le mueve su amor (trahit sua quemque voluptas: Virgilio, Églogas, II, 65). Pero el amor no es una falsa exaltación ni una simple sumisión o confusión. "Con el amor crecen juntos el que da y el que recibe, el ofendido que perdona y el ofensor perdonado. Desbloquea la rigidez inelástica de la ley, de la voluntad, del puro control, del hegemonikon. Incluso en su etapa de máximo extravío, el deseo más vivo y ardiente de Agustín era amar y sentirse amado"(Conf II,2,2).

El amor es un antídoto para la falsa obediencia y el temor. En ese sentido, está tan lejos de la pura sumisión como de la parálisis inactiva. Así, "la llama del amor consuma y supera los conflictos, extrayendo de ellos su propio alimento en el mismo momento en que los destruye y transformando en inquieto ímpetu hacia lo alto su tendencia a permanecer atrapados en el cuadro de una lógica de perpetuo aplazamiento y multiplicación inane de los esfuerzos (...) El amor -sinónimo a veces de memoria- perdona, reformulando el sentido de los recuerdos a través de una mayor comprensión del presente y un más audaz encauzamiento de la voluntad hacia el futuro"19.

Esto puede verse, muy bien, en los estudios de H. Arendt, R. Canning, T. van Bavel, sobre Agustín, donde se muestra que al liberarse la voluntad de sus antiguas cadenas se convierte en un amor que es un novum, un nuevo comienzo total, un principio de amor dinámico "que mueve todas las cosas hacia un fin, que articula lo múltiple en lo uno y especifica lo uno en lo múltiple". Es el amor que mueve el mundo y lo renueva, y se muestra en las estaciones anuales como un poema de muerte y resurrección presente siempre entre el invierno y la primavera.

${ }^{19}$ R. BODEl, op. cit., p. 75. Remarcado nuestro. 
Entonces, el amor es constancia, esfuerzo, determinación, paciencia, generosidad, pero también memoria sui, acordarse de sí mismo: "Pero, sobre todo, el amor intenta recuperar la memoria de la felicidad entrevista para re-actualizarla y para romper el envoltorio de un pasado congelado, para desatarlo y encauzarlo hacia un futuro abierto"20. Así, retira a los hombres el peso de su pasado, los regenera y los restaura en su presente (Baudelaire). Y, en este proceso, como dice el mismo Bodei, memoria, perdón y amor: "Son producción repetida de un initium, incesante inauguración de lo nuevo que todo hombre es capaz de producir".

De este modo, la memoria no es sólo un amor anticuario del pasado sino que crea futuro y nueva esperanza. "Se transforma al compás de nuestros propios cambios y se articula con nuestras propias concatenaciones según esquemas reformulables, referidos simultáneamente a nosotros mismos tal como fuimos, como somos y como proyectamos ser (...) De este modo se cumple y se renueva, a cada instante, una misión confiada por Dios al hombre: para que hubiera un initium, justamente para eso, creatus est homo (San Agustín, civ. Dei, XII,10 s.)"21.

A través de esta anamnesis renovadora, volvemos al núcleo de nuestra vida, y hacemos memoria del pasado, del presente y del futuro. Es la vuelta a la propia casa para tomar posesión de nosotros mismos. Así, la memoria es nuestro horizonte vital, y el amor un ars inveniendi de soluciones nuevas que se renueva como un hontanar perenne, pues: "El amor, en cuanto memoria, constituye la resurrección continua en el tiempo de aquella eternidad ya conocida y olvidada, antigua y nueva, que trabaja dentro de nosotros y que lleva la inquietud a nuestros corazones".

Y, es muy consolador saber que "el amor nunca se acaba" (1Cor 13,8), pues: "hay enclaves de amor que permanecen tenazmente polarizados hacia el bien, incluso cuando están rodeados y envueltos por el mal. El peor bandido, que, sometido al tormento, se niega a revelar los nombres de sus cómplices, no podría actuar así si no estuviera iluminado por la luz del amor (San Agustín, Sermón 169,14)".

Así, podemos reconocer y recuperar nuestra identidad, al menos momentáneamente, y nos consuela la esperanza de rescatar y articular nuestro ser y el de nuestros prójimos. Entonces: "El reconocimiento o la agnición constituye un doble conocimiento y una doble felicidad: significa rescatar y recuperar la pérdida de nosotros mismos y de nuestros seres queridos y, a la

20 Ibid., p. 90.

21 Ibid., pp. 92-3. 
vez, la de lo divino, significa salir, en el ekstasis, dẹ la concentración del yo en sí mismo para reencontrarlo, más tarde, intensivamente potenciado en Dios"(....) "En este sentido, el amor es un "principio del devenir" que empuja a los hombres a generar en sí mismos un Sé mejor y a descubrir en el mundo un orden más satisfactorio"22.

El amor es una lanzadera que teje y reteje la trama, deseante y animosa, de la memoria de la vida en relación con el logos. Así Eros y logos se complementan. "Eros se ve, pues, inducido a desdoblar el alma en sí misma y a incitarla, sin concederle tregua, a renovados escudriñamientos de sí a través de los otros y de los otros a través de sí". Y sólo la autoafirmación infantil, prisionera de la envidia, excluye, siempre, a los otros.

Así pues: En la búsqueda de la felicidad se revela la existencia de una 'trinidad humana' compuesta de intelligentia, voluntas y memoria (concepto que a veces se superpone al de amor) que dialoga entre sí y con Dios. Y ese diálogo, no es vana curiosidad, ya que es un "conocimiento que no tiene otro fin que sí mismo".

Además, Agustín rechaza el primado del conocimiento como forma de dominio de sí y del mundo, pero tampoco el hombre es mera voluntad de poder o libido dominandi ni es solamente deseo y amor como en Spinoza. Como dice el mismo Bodei: "Es la estructura relacional y unitaria constitutiva del hombre la que prohíbe separar al entendimiento de la afectividad y la decisión, la que guía sapientemente la voluntad hacia su objeto y la que transforma el amor en perspicacia intelectual y actividad transformadora".

El niño, el artista y el buen salvaje, "campeones de una genuina humanidad", no deteriorada por la civilización, simbolizan los movimientos espontáneos del corazón y los sentimientos, la vida en todo su esplendor. "De este modo, el yo se prepara para la agnición final, en la que le misterioso núcleo de la alteridad cerrada en sí se abrirá de improviso en el fulgor de una revelación, de una apokalypsis, cuando todas sus facultades, comprimidas en esta vida, florecerán plenamente en la otra"23. Ese núcleo misterioso es el verdadero yo que siempre intentamos buscar, encontrar y desvelar.

Agustín descubrió, en la memoria y la interioridad, el camino del renacimiento personal y el rescate de los vínculos de la vida en sociedad (socialis est vita santorum). Como lo dice Bodei: "La memoria es la tradición del individuo, el hilo conductor de su identidad auto-renovadora, mientras que la tradición es, por su parte, la memoria colectiva".

\footnotetext{
22 Ibid., pp. 106, 112-113. Remarcado nuestro.

23 Ibid., p. 134.
} 
P. Ricoeur, intenta dar estatuto filosófico al reconocimiento humano, para liberarnos de la marea mercantilista e imperialista, y mostrarnos que todo persona sana le hace siempre bien a la otra. En todo este proceso nos ayudará, sin duda, mucho, la experiencia de Rousseau, cuando dice:"Tan pronto como un hombre fue reconocido por otro como un ser sentiente, pensante y semejante a él, el deseo o la necesidad de comunicarle sus sentimientos y sus pensamientos le hizo buscar los medios para ello"24.

\section{QUÉ ES Y QUÉ NO ES LA DIRECTIVIDAD}

Una vez conocido el problema de la directividad y el verdadero sentido y valor de la no directividad, vamos a tratar de precisar un poco más estos conceptos, sobre todo teniendo en cuenta su experiencia práctica y su desarrollo en la relación de ayuda.

Desde el punto de vista metodológico, "la no-directividad se traduce en una postura en base a la cual el terapeuta se niega a orientar al cliente en una determinada dirección, y evita llevar al individuo a pensar, sentir y actuar según un esquema determinado"25.

Desde el punto de vista psicológico, la no directividad es la consecuencia concreta de la teoría de la personalidad de Rogers y los psicólogos humanistas. Para ellos, en unas condiciones favorables, al proceso de crecimiento y desarrollo, la energía organísmica de la persona se activa y "opera de manera constructiva" su propia autorrealización, que valora como decisivo el componente afectivo, el presente frente al pasado y la persona sobre la enfermedad. Por eso, no necesita de estructuras psicológicas ni condicionamientos impuestos desde fuera.

Pero, según Rogers, la no-directividad no puede ser eficaz sino como parte integrante de una filosofía de la persona, que no puede reducirse nunca a pura técnica ni ser un mero utensilio sino que da plena confianza a la persona para conocerse a sí misma, asumir su propia experiencia, y ejercer su capacidad de recuperación y crecimiento.

Una forma concreta de entender todo esto es el convencimiento de que la persona es el único ser experto en su propia vida. De ahí que Saint-

\footnotetext{
24 P. Ricoeur, Caminos del Reconocimiento, Trotta, Madrid 2005, p. 157.

25 B. Giordani, La relación de ayuda: De Rogers a Carkhuff, Desclée de Brouwer, Bilbao 1997, pp. 103-4.
} 
Arnaud proponga que el estilo no directivo consiste en asumir una postura de "docta ignorancia" ante las vivencias propias de cada persona, para que sea ella la que oriente y dirija su propio proceso de conocimiento, comprensión y cambio.

Esto no impide, sino que supone, que el asesor es experto en la dinámica de relaciones interpersonales, en el método adecuado para abordar los problemas que se presentan y en la posibilidad de su orientación más apropiada.

De ahí que, según B. Giordani, que recoge ideas de Rogers, la no directividad no consiste en "evitar ejercer cualquier influencia"26, sobre la persona asesorada, sino en que el orientador prescinda de prejuicios y modelos prefabricados de valorar y orientar a la persona. Pero supone también que invita a "estimular activamente" a la persona para que pueda aclarar su situación interior y tomar decisiones constructivas.

Tampoco se deber equiparar, la no directividad, a la idea de laxismo o un modo de "laisser faire". Por tanto, no se trata de aceptar cualquier capricho de la persona, pues aceptarla incondicionalmente no es convalidar toda conducta, sea moral o inmoral, constructiva o destructiva.

Tampoco es no directividad, una postura arbitraria en la que el asesor "no se involucra" en el apoyo al cliente. Y, así como no es adecuado confundir empatía con simpatía, es también impropio del counsellor "remitir al cliente a sí mismo" o no hacer caso a la persona, escondiéndose detrás del aparato técnico o simplemente detrás de la desidia.

Un última forma errónea de entender la no directividad es considerarla como un "fin en sí misma", o como una valor absoluto. Con esta manera de actuar, el asesor se vuelve cada vez más directivo y autoritario y el asesorado abandona su proceso de crecimiento. Por eso, precisa Rogers: "lo importante, no es la ausencia de directrices, sino la presencia en el terapeuta de ciertas actitudes respecto al cliente y de una cierta concepción de las relaciones humanas"27.

Una manera acertada de presentar la no directividad es la idea de que el counsellor es padre y madre, porque la intervenciones formadoras de ambos son entre sí complementarias y producto del amor. Así la mujer ayuda a dar vida, conservarla y promoverla, con una gran sensibilidad y capacidad receptiva sin ser meramente pasiva ni posesiva. $\mathrm{Y}$ el hombre maduro es muy capaz de animar con energía y de proponer una ley y orden

26 Ibid., pp. 103-4. J. C. BERMEJO, op. cit., pp. 63-4.

27 B. GIORDANI, La relación de ayuda: De Rogers a Carkhuff, p. 108. 
que orienta hacia la acción y la iniciativa, sin imponer su propia ley ni la propia iniciativa que ahogaría al hombre nuevo.

Por tanto, no se trata de elegir entre un asesor muy maternal o un padre autoritario que son dos modos excesivos del ser humano, sino de integrar lo mejor del hombre y de la mujer tal como hoy los entendemos. Hacia ahí parece apuntar también R. Carkhuff cuando dice: "Es evidente que el consejero eficaz podrá asumir según el caso el rol de una mujer y un hombre, masculino y femenino, y más precisamente según esta modalidad: asume el papel materno generalmente con aquellos que han sido suficientemente nutridos a nivel afectivo; y hace de padre, especialmente con aquellos que tuvieron ya en su infancia modelos adecuados para una acción claramente orientada; será según el caso madre y padre con los clientes -muy numerosos- los que resultan con falta de una y de otra experiencia" 28 .

$\mathrm{Al}$ principio, el asesor deberá hacer ver a la persona ayudada que es acogida, (escuchada), comprendida, respetada en toda su forma de ser y situada en el centro mismo de la relación de ayuda. Pero, poco a poco, el asesor orientará a la persona a medirse personalmente con sus problemas (personalización) y, por tanto, a tomar decisiones y compromisos y asumirlos con responsabilidad propia (iniciar). En otro caso, la persona ayudada sería como un niño cogido a la falda de su madre, en infancia permanente.

En ese sentido, Carkhuff caracteriza como femeninas las intervenciones de respuesta empatía y respeto mientras que considera masculinas las de iniciativa, en las que aparecen la confrontación y la relación de inmediatez. $\mathrm{Y}$ piensa que, en un proceso de ayuda eficaz, han de estar siempre representadas tanto la dimensión femenina como la masculina del ser humano. El grado de intensidad de una y otra dependerá de las necesidades del cliente. Las tres cualidades de concreción, confrontación e inmediatez, según Repetto, pueden considerarse más bien masculinas mientras que la aceptación, la congruencia y la empatía serían, más bien, femeninas. Pero como lo recoge B. Giordani: "El verdadero terapeuta es a la vez madre y padre".

O como lo dice Rogers: todo aquel que actúa de una manera expresiva, afectuosa y respetuosa, y cuida de las personas, sin ser posesivo, "facilita la autorrealización de la misma manera que los padres". Se trata de personas que crean confianza, sentido de comprensión y impulsan la independencia y la madurez libre en la persona ayudada.

Según J. C. Bermejo, la relación de ayuda directiva es autoritaria, paternalista, centrada en el problema, hace cosas por el otro pero sin contar con

28 Ibid., p. 221. 
él, mientras que la relación de ayuda facilitadora, no directiva, crea un estilo democrático, cooperativo, participativo y empático, centrado en la persona y en todas sus dimensiones, recursos y valores ${ }^{29}$.

Según José Parra, el counselling puede considerarse no directivo cuando:

"1. Tiene su centro en el aconsejado, 2. La persona se vuelve el centro del proceso, 3. (el) énfasis está en aprender. 4. pone su énfasis sobre la dimensión de lo afectivo que es la de los sentimientos y la emoción, 5. el proceso se hace con el individuo, 6. la actitud es democrática. 7. asume poca responsabilidad por el tema de la conversación"30.

A su vez, el counselling es directivo, según el mismo J. Parra, cuando:

" 1 . Se centra en el consejero, 2. el problema es el centro, 3 . se da el énfasis a la enseñanza, 4. énfasis a lo cognoscitivo, que tiene que ver con el proceso de percibir y saber, 5. el proceso de consejo es para el individuo, 6. actitud de autoridad y 7. asume mucha responsabilidad en ello".

Según las investigaciones de W. U. Snyder y de J. Seeman pueden señalarse, como características de un modo de proceder directivo, ciertas posturas que identifican al asesor como tal. Así ocurre cuando el consejero:

1. Establece la situación (con firmeza), 2. Fuerza la elección y el desarrollo de la conversación, 3. Hace preguntas directas, y 4. Lleva la dirección de un modo indirecto. Mientras que pueden considerarse como propias del método no directivo: 1 . Simple aceptación, 2. Repetición de contenido, 3 . Clarificación de sentimientos ${ }^{31}$.

En este último caso, según Rogers, queda claro que "el cliente es el que ha de resolver su problema, aun cuando el counselor procurará ayudarle en ello". No se trata de hacer algo "para" la persona ayudada, sino de pensar, desarrollar y vivir un proceso, juntamente, "con" ella.

Ahora bien, según el mismo José Parra: "No se sabe por adelantado qué tan directo o indirecto debe ser el consejero en un caso dado". Para Parra, la literatura de este campo, sugiere que las personas más jóvenes, menos maduras y con menos conocimientos recibirán mejor ayuda con un asesoramiento más directo, mientras que las personas con más madurez, edad o educación responderán mejor a un método menos directivo.

29 J. C. BERMEJO, op. cit., pp.15-23.

30 J. PARRA, Modelo práctico de técnicas de counselling: counselling Pastoral, (Apuntes), Centro de Humanización de la Salud, Madrid 2005, p. 6.

31 H. ITO, Introducción al counselling. El pensamiento de Carl R. Rogers, Fax, Madrid 1971, p. 159. 
"Sin embargo, todo consejero con experiencia sabe que esta teoría no siempre da buen resultado". Y que es la relación interpersonal, que precede a la técnica, la que, en la sesión misma de consejo, dirá cuál es la mejor técnica con una persona determinada en un momento dado. Según Rogers, la "no directividad" sólo "puede ser eficaz" si forma parte de una filosofía fundamental de la persona que supone confianza firme y una consideración positiva y afectiva, es decir, un verdadero amor a la persona ayudada.

La manera concreta de afrontar la situación, en que se encuentra una persona, depende también de la naturaleza de los estresores y las circunstancias en que se produce. Concretamente, en una situación especial, como es la intervención en crisis: "En términos generales, las situaciones en las que se puede hacer algo constructivo favorecen estrategias focalizadas en la solución del problema, mientras que las situaciones en las que lo único que cabe es la aceptación favorecen el uso de estrategias focalizadas en las emociones (Forsythe y Compas 1987)"32.

E. Repetto, insiste en recordar que el orientador es el que presta ayuda y el aconsejado el que la pide. Pero, según C. Rafael Cabarrús, quien hace de piedra de moler debe ir al ritmo de la persona acompañada, ayudarle a profundizar en su experiencia personal, en sus propias sensaciones, y animarle a potenciar su propio manantial, "sin adoptar una postura directiva". "Esta destreza, es lo que hace que quien acompaña sea realmente un(a) Pigmalión, porque es capaz de recoger las fuerzas positivas que la misma persona acompañada no reconoce" 33 .

Según Rogers, la experiencia para determinar los elementos más útiles para la modificación constructiva de la personalidad le ha llevado poco a poco a elaborar un enfoque de la psicoterapia que ha sido denominado "no directivo" o "centrado en el cliente" que se basa en la confianza en la persona y sus capacidades para avanzar en el concepto y aceptación de sí misma y su integración con los demás.

En ese sentido, lo que es el consejero es más importante que lo que hace, pues sólo así podrá aportar autenticidad, aceptación incondicional y verdadera empatía a la relación de ayuda, con "una gran confianza en la evolución decidida por el consultante". En todo caso, la relación de ayuda no directiva no se centra en el consejero ni tampoco en el problema sino en la persona ayudada.

32 J. Martín Oterino, Counselling en situaciones de Crisis, (Apuntes), Centro de Humanización de la Salud, Madrid 2006, p. 24.

33 C. R. CABARRÚs, Cuaderno de Bitácora, para acompañar caminantes. Guía psico-histórico- espiritual, Desclée de Brouwer, Bilbao 2001³ , p. 132. 
De ahí, la importancia especial que tiene en este proceso la actitud de empatía, por la que el consejero, como dice Y. Saint-Arnaud: "procura penetrar en el mundo subjetivo de su interlocutor, con la intención de ver las cosas tal como el otro las ve, sin añadir nada, privilegiando sin embargo las resonancias afectivas y emotivas que suscita". Así el aconsejado "es quien aparece como el responsable de la consulta".

Entonces: "la denominación "no-directiva" expresa el propósito de considerar al "cliente" más importante que al terapeuta y la intención de no dirigir el proceso terapéutico"34. O como dice V. Frankl: "El terapeuta no impone nada. Antes bien, "el enfermo debe avanzar por sí mismo hacia el sentido concreto de su existencia personal".

Finalmente, la relación de ayuda no directiva se caracteriza por el silencio respetuoso que alienta el auto-conocimiento de la persona ayudada, la reformulación, como dilucidación y clarificación o la simple reiteración que asegura al aconsejado de haber sido comprendido, el reflejo del sentimiento que recoge la carga emotiva que afecta a la persona ayudada en el mismo momento en que se produce, con toda su frescura y significado. Se trata de ponerse en el lugar del otro "como si yo fuera él mismo", entrando en su intimidad, captando sus sentimientos y los significados de los mismos, para percibirlos desde dentro como lo hace la misma persona ayudada. Así, como dice Y. Saint-Arnaud: "toda mi energía se emplea en acompañar a mi interlocutor en la arriesgada inmersión que debe efectuar en el fondo de sí mismo".

Es también importante, la aportación de información que a petición del consultante hace el consejero, pero sin asumir el papel de experto, pues "nadie es más competente que el sujeto mismo que vive ese problema". Por esa razón, con frecuencia, se prefiere la expresión de terapia "centrada en el cliente" a la otra, más indefinida y general, de terapia "no directiva". Pero, en ambos casos, se subraya la importancia de "las motivaciones internas" y la ausencia de "presiones externas", pues, el proceso y el cambio, "es mucho más fuerte cuando procede de él (asesorado)" aunque sea, también, más largo y lento.

Y, además, porque ser directivo "entorpece el desarrollo del otro", le impide "madurar", no se respeta "su libertad", se corre "el riesgo de usurpar el lugar del otro", de asumir, en vano, la responsabilidad de la otra persona "y en ese momento sustituirle". Por eso, aunque Y. Saint -Arnaud no quiere pronunciarse, definitivamente, sobre el tema de fondo, cuando se

34 J. SEgurA, "Carl Rogers", op. cit., p. 94. 
trata de pastoral, deja el tema bien orientado, pues, como dice uno de sus encuestados, al final de su libro: "Creo que la actitud de Dios a nuestro respecto es una actitud no directiva".

\section{LAS CONDICIONES NECESARIAS Y SUFICIENTES DE LA EFI- CACIA DEL COUNSELLING SEGÚN ROGERS.}

La relación de ayuda o relación terapéutica propuesta por Rogers se ha descrito siempre como una terapia no directiva o centrada en el cliente. Aquí vamos a ver cómo entiende Rogers su método, las condiciones del mismo que él considera fundamentales, su influencia en la eficacia terapéutica, así como su apuesta por la no directividad.

Según los estudios que se han ido realizando parece que se puede afirmar que el cambio positivo de la persona no se debe nunca, exclusivamente, a una escuela o teoría psicológica sino que hay que atribuirla a un conjunto de elementos capaces de favorecer o dificultar el proceso. Y, hoy puede afirmarse, "con suficiente base científica" que, con independencia de las teorías de cada escuela psicológica, hay, según Rogers, "un núcleo de dimensiones (core conditions) que son cruciales a todo proceso interactivo"35.

Así pues, según Rogers, si tenemos una alianza entre dos personas para la relación de ayuda, en la que una siente cierto desacuerdo interno, vulnerabilidad o angustia, y la otra o ayudante se encuentra en estado de acuerdo interno o congruencia, y experimenta una consideración positiva incondicional hacia el ayudado y una compresión empática de su marco de referencia interno, de modo que el otro lo perciba, entonces se puede decir, que la eficacia de la terapia está garantizada. Y añade Rogers: "Ninguna otra consideración es necesaria" 36 .

Estos factores son como la explicación de la mayor parte de los resultados positivos de la terapia y poseen, de hecho, una gran fuerza en casi todas las escuelas. Esto es así, porque se ha comprobado que los asesores expertos establecen una relación de ayuda más cercana a la persona y al 151.

35 E. REPETTO, La personalización en la relación orientadora, Miñón, Valladolid 1977, p.

36 C. ALEMANY BRIZ, Evaluación del entrenamiento en destrezas interpersonales del modelo de Carkhuff, Universidad Complutense de Madrid 1984, t. I, 69. 
ideal de relación humana con independencia de su escuela. Todos muestran una especial habilidad para comprender, comunicar y mantener contacto con la persona ayudada. Y parece ya demostrado que la relación interpersonal es la clave del proceso de cambio ${ }^{37}$.

Más en concreto, la primera condición de una relación de ayuda, sería el interés cálido y auténtico por la persona, la aceptación de su dignidad de ser humano y un gran esfuerzo por comprender sus sentimientos. En este sentido, se trataría, para Rogers, de: "una sensible empatía con cada uno de los sentimientos y expresiones del cliente tal como se le aparece en ese momento".

La segunda condición sería la "permisividad no punitiva" o respeto a la vida y los sentimientos de la personas para que la persona ayudada pueda hablar con libertad y comunicar sus dificultades sin miedo a ser rechazada. Esta condición, según Rogers consiste en que: "cuanto mayor sea la aceptación y el agrado que experimento hacia un individuo, más útil le resultará la relación que estoy creando".

La tercera condición, sería la honestidad con las personas o autenticidad en la relación. En este sentido, como dice Rogers: "He descubierto que cuanto más auténtico puedo ser en la relación, tanto más útil resultará esta última"38.

Carkhuff, ha hecho un gran esfuerzo para sintetizar esas cualidades fundamentales de la relación de ayuda, independientemente de que estemos ante la escuela del psicoanálisis, la terapia centrada en el cliente o el conductismo. Y, sus resultados, se pueden resumir así: 1. Importancia de la integración, madurez, genuinidad y autenticidad del terapeuta, 2. Eso vale para la aceptación incondicional, la cordialidad no posesiva, la atmósfera de confianza y amor creado por el asesor. 3. Y la capacidad de empatía, comprensión y sintonía con las dificultades, sentimientos y potencialidades de la persona ayudada.

En realidad, estas claves ya las dio Freud al exponer lo que era una "conversación curativa", pero hoy son aceptadas por todos lo especialistas de la distintas escuelas, incluidos los eclécticos. La exposición detallada y concreta de estas condiciones, la hace Rogers al presentar "las condiciones necesarias y suficientes de la eficacia terapéutica".

Como lo dice Carkhuff : "Rogers fue, sin embargo, uno de los primeros en darles una especial prominencia al considerarlos como los ingredientes

\footnotetext{
37 M. MARroquín, op. cit., pp. 42-3.
}

38 C. ROGERS, op. cit., p. 41. 
efectivos de la terapia exitosa". Ese éxito se considera algo medible, por los psicólogos clínicos, en una mayor integración de la persona, menos conflictos internos, más energía vital, y cambios de conductas considerada inmaduras a otras maduras.

Según Marroquín, que recoge el estudio de Rogers, las condiciones de eficacia propuestas por Rogers, más que técnicas, son actitudes en el proceso de ayuda, y se reducen a tres: "La congruencia, la consideración positiva incondicional, y la comprensión empática"39.

En cuanto a la congruencia, transparencia o autenticidad, se trata, según Marroquín, de que el terapeuta pueda acceder, verdaderamente, a sus propios sentimientos y esté en disposición de comunicarlos de modo que la relación sea auténtica, sincera y real. Se trata de reconocer los sentimientos propios sin ocultarlos ni falsearlos. Además, es necesario comunicarlos sin enmascararlos tras una fachada que falsearía la relación, le haría perder su autenticidad e invitaría a hacer lo mismo a la persona ayudada.

Se trata de una autenticidad existencial que hace la relación verdadera e impide colgarse de las técnicas sin implicarse en esa relación, con toda la persona entera y su vida personal. Para Rogers, se trata de una cualidad "altamente importante, quizá la más crucial de la condiciones que pienso describir", pues, como se ha dicho, la autenticidad está íntimamente unida a la eficacia.

La primera implicación de la autenticidad, en la relación de ayuda, según J. C. Bermejo, es "no decir aquello que ni el mismo ayudante se cree o piensa". Un segundo nivel, de mínimos, de acuerdo con Kübler-Ross, sería aceptar que no tenemos respuestas para todo ni hemos de aparentar lo que no somos. Finalmente, la congruencia o autenticidad es la "integración entre experiencia, conciencia y comunicación".

Es decir, el núcleo fundamental de la persona, la mismidad de su ser y la expresión de su yo íntimo están en buena sintonía y eso invita a la transparencia. Se trata del proceso por el que cada uno se hace a sí mismo, como dice M. Yela, se ve a sí mismo como es y expresa lo que hace. Así, uno puede integrar bien todas sus experiencias aun cuando parezcan contradictorias.

Esto no quiere decir que se deba proceder con una sinceridad tan espontánea que constituya al ayudante en el centro del encuentro, en sustitución de la persona ayudada. Pero, sí es necesario comunicar los propios sentimientos, aunque no sean muy cómodos, para levantar las barreras en la relación de ayuda. En ese momento de su vida, Rogers ya ha apostado por

39 Ibid., p. 46. 
la terapia existencial y su gran preocupación consiste en entrar, con toda su persona, en la relación para "crear un auténtico encuentro existencial".

La segunda condición necesaria y suficiente establecida por Rogers es la consideración positiva incondicional, o aceptación incondicional. Se trata de una experiencia cálida de aceptación de todos los aspectos importantes de vida de la persona ayudada. Esta cualidad fue una de la más características de "los escritos "no-directivos" de la primera época". Es una actitud de aceptación plena y total de la persona ayudada y sus sentimientos, de forma incondicional, y se opone a toda evaluación selectiva, positiva o negativa, de la vida de la persona.

Además, la aceptación incondicional lleva consigo una actitud de respeto hacia la persona ayudada y a un interés positivo por su vida y por ella misma. Según Marroquín, es indudable que esta aceptación incondicional es imposible sin "una profunda convicción filosófica relacionada con la autodirección y autodeterminación del individuo" 40 . En efecto, la acogida total de la persona y la cordialidad supone una confianza positiva, en la misma, que elude toda directividad, le anima a ser ella misma y a entrar en relación con "lo más íntimo de sí mismo y con los demás".

Como dice J.C. Bermejo, en sintonía con B. Giordani: “el ayudante evita dar órdenes o directrices, exhortar o moralizar, dar consejos y formular soluciones hechas, expresar juicios positivos o negativos, poner en ridículo o ironizar sobre las confidencias del ayudado, utilizar etiquetas, investigar o juzgar el tema en una determinada dirección, imponer el propio criterio sobre lo que es bueno o malo, emitir un veredicto sobre la persona y sus comportamientos" 41 .

Según Rogers, este proceso supone un gran amor por la persona ayudada semejante al ágape cristiano que, no es romántico ni posesivo, respeta a la otra persona y por tanto no es paternalista ni superficial, y lleva a la aceptación incondicional del otro.

Para Rogers, los condicionamientos negativos de los padres dificultan a la persona su vivencia personal. El consejero lo que hace es facilitar el camino de retorno de modo que la persona pueda aceptarse incondicionalmente, con toda su experiencia positiva y negativa, como es y sin verse amenazado. Así, la aceptación del ayudante determina en el ayudado, "una mayor aceptación de sí mismo", y una nueva convicción de sus posibilidades personales de cambio y éxito en la vida.

\footnotetext{
40 Ibid., p. 52 .

41 J. C. BERMEJO, op. cit., p. 60.
} 
La aceptación incondicional no supone convalidar todas las conductas, morales o amorales, sino darles un contexto apropiado de explicación para que la persona pueda aceptarlas e integrarlas y, en su caso, rehacerlas.

Sobre la aceptación incondicional, Rogers hizo algunas precisiones, en 1962, pues, algunas personas, especialmente psicóticos, percibían la aceptación incondicional como falta de interés por parte del ayudante, al que todo le daría igual. No obstante esto, Rogers ha reafirmado esta teoría, aunque la haya enriquecido con la idea de respeto, presencia cálida y cercana, a la persona ayudada, con amor no posesivo. Como dice Marroquín: "Esta incondicional aceptación ha sido indudablemente la más antigua de las condiciones necesarias y suficientes por él expuestas".

La tercera condición, de Rogers, para que se produzca el cambio, en la persona ayudada, es la "comprensión empática correcta que el cliente tiene de su propia experiencia", como si fuera la propia. Pero no hay que confundir empatía con simpatía. Se trata de captar plenamente el punto de vista del cliente, con toda profundidad, tanto en sus planteamientos como en cuanto a sus sentimientos. De este modo nos hacemos capaces de sentir con el otro, conocerle de primera mano, y superar la sordera emocional y el analfabetismo emocional que, con frecuencia, padecemos, sin darnos cuenta.

Rogers, describe esta $3^{\text {a }}$ condición de la relación de ayuda o "comprensión empática" así: "Cuando el psicoterapeuta percibe los sentimientos y significados personales que el cliente experimenta en cada momento, cuando puede percibirlos desde "adentro" tal como se le aparecen al cliente y es capaz de comunicar a este último una parte de esa comprensión, ello implica que esta tercera condición se ha cumplido"42.

Según, el mismo Rogers, si el asesor es coherente, acepta incondicionalmente al ayudado y "comprende los sentimientos esenciales de este último tal como él los ve, entonces existe una gran probabilidad de lograr una relación de ayuda efectiva". Bergin y Salomón descubrieron que la empatía cuidadosa estaba relacionada, de forma muy significativa, con los resultados positivos del proceso de ayuda. Cuando la comprensión empática es buena, el ayudado se da cuenta que el ayudante ve lo que él siente, y que es una persona abierta a sus sentimientos. Según van Kaam, entonces el ayudado siente un gran alivio a su soledad y una comunión profunda con el ayudante.

Se trata de desarrollar, plenamente, la inteligencia emocional ${ }^{43}$. Así, al sumergimos en el mundo del otro, captamos su experiencia, en todas sus

42 C. ROGERS, op. cit., p. 65 . pp. 158-9.

43 D. Goleman, Working with Emotional Intelligence, Bantam Books, New York 1999, 
dimensiones, percibimos sus propios sentimientos y nos empapamos de ellos, sin dejarnos confundir por ellos. El buen asesor tiene siempre abiertas sus antenas a los sentimientos del otro. Según J.C. Bermejo: es un verdadero "radar emocional que nos permite navegar con acierto en el mar de nuestras relaciones", desarrolla el "crecimiento autónomo" de la persona y la hace dueña de su vida.

Se trata de una "vivencia existencial" que hace al acompañante un verdadero compañero de camino de la persona ayudada, y que, como dice Rogers, "le permite ver el mundo a través de los ojos del cliente", sin caer en el mecanismo de identificación. La empatía es una comprensión cuidadosa (Egan), delicada y sensible del mundo interior y profundo de la persona ayudada, pero sin adelantarnos a sentimientos que ella aún no percibe. Es como dejar de lado el propio yo, para entrar en el extraño mundo del otro, sin miedo a perderse en él, siendo sensible a cuanto siente la persona para captar sus cambios, "momento a momento".

La actitud empática compromete toda la vida del ayudante a entrar en el campo perceptivo y en la experiencia afectiva de la persona ayudada. Además, es necesario expresar con claridad esa empatía, con el lenguaje hablado y con los para-lenguajes, para que el otro se sienta acogido, escuchado y comprendido en todo el proceso de alianza terapéutica. La comunicación de la experiencia empática "suele concretarse en respuestas no directivas, centradas en la persona y que explicitan lo que se ha comprendido, desvelando sentimientos y significados, trayéndolos a la superficie, poniéndoles nombres y apellidos" 44 .

Finalmente, Rogers quiere dejar claro que las tres condiciones de aceptación incondicional, autenticidad y empatía se aplican a todo tipo de personas y terapias, sin excepción, y a toda relación humana auténtica. Además, no es necesario que el ayudante sea un profesional ni que haga unos diagnósticos ni con tests ni por otros medios.

Hoy día, otros expertos han confirmado la teoría de Rogers. Así, muchos psicoanalistas consideran que el terapeuta debe responder, realmente, al paciente y no sólo reflejar sus balbuceos. También se subraya el interés del terapeuta por el paciente y la necesidad de no contaminar la relación terapéutica con sus propios problemas.

Del mismo modo, Whitaker y Malone han destacado la necesidad de no ocultarse tras la fachada del papel profesional, e insisten en que mostrar la

44 J. C. BERMEJo, Inteligencia emocional. La sabiduría del corazón en la salud y en la acción social. Sal Terrae-CEHS, Madrid 2005, pp. 106-7. 
autenticidad de un verdadero ser humano, en una auténtica relación humana, facilita el cambio hacia la madurez de la persona ayudada. Del mismo modo, otros autores han insistido en la importancia de la naturalidad en la relación, con un sentido de amor y encuentro personal profundo. No hay, pues, alternativa a la autenticidad en la relación de ayuda.

En cuanto a la aceptación incondicional o "cordialidad no posesiva" no es una actitud admitida de una forma tan universal. Algunos creen que es una forma de suplir "el tremendo déficit de amor experimentado por el paciente", por la que el ayudado se va a sentir libre y sin temor, mientras que el ayudante permanece siempre cordial, pase lo que pase, en el proceso de ayuda, y así suscita la confianza y la autoexploración del ayudado. En realidad, se trata de que la persona "se sienta amada con ese amor que permite al otro vivir lo que debe vivir" y "hacerse responsable de sí mismo", de modo que le confirme en su "autonomía".

Esta aceptación cordial es una elemento fundamental en la teoría psicoanalítica según Truax y Carkhuff. La naturaleza no evaluadora del papel de psicoanalista fue subrayada por Freud, en 1912, y ha sido aceptada por todos los métodos de psicoterapia relacional y expresiva, asegura M. Marroquín.

El valor de la empatía, en la relación de ayuda, ha sido subrayado por Kagan y Truax, entre otros, como fuente necesaria de conocimiento y comprensión de la persona. Para Carkhuff es también una clave esencial: "Sin empatía no existe base para la ayuda", recuerdan Marroquín y J.C. Bermejo. En cambio, es menos valorada por los conductistas. Por lo que hace al psicoanạ́lisis, lo considera "una base indispensable para el diagnóstico del cliente". Th. Reik, al hablar del "tercer oído", intenta promover la importancia de la receptividad para captar los sentimientos de la persona ayudada. Desde este punto de vista la empatía es, para el psicoanálisis, "algo esencial".

No obstante, el psicoanálisis defiende que, a veces, además de la empatía, es necesario el conflicto para que la persona "viviendo su propia crisis, se explore a sí misma", como dice Repetto. Truax y Carkhuff, creen que, en la forma de actuar, las escuelas psicoanalíticas y las centradas en el cliente, son bastante convergentes.

Así pues, según Marroquín, se puede concluir que hay un núcleo de condiciones primarias comunes (core conditions), a casi todas escuelas terapéuticas, que fueron defendidas por Rogers como condiciones "necesarias y suficientes" de la alianza terapéutica para el cambio positivo de la persona ${ }^{45}$.

\footnotetext{
45 M. MARRoQuín, op. cit., p. 61.
} 
Esas tres condiciones fundamentales fueron evaluadas, en relación a su eficacia terapéutica, por Truax y Carkhuff, entre otros. Se vio que, por ejemplo, la comprensión empática es más eficaz desarrollada como "empatía correcta" o cuidadosa y que tiene, a veces, elementos cercanos al psicoanálisis.

También se vio que la aceptación incondicional era más eficaz cuando se desarrolla como "cordialidad no posesiva". En cuanto a la congruencia, se vio que es muy importante que el terapeuta no presente una postura defensiva, de pura fachada o de puro engaño. Según Rogers, la autenticidad o coherencia nunca puede llegar a ser total, pero el grado de coherencia será mayor en la medida que el terapeuta logre "aceptar lo que sucede en él" y "ser sin temor la complejidad de sus sentimientos".

Por lo general, todos los autores estuvieron de acuerdo en subrayar la gran importancia de la empatía para el buen resultado del proceso terapéutico. Para Rogers: "Nuestra investigación nos ha enseñado que esa comprensión empática -comprensión con la persona, no sobre ella- es un acercamiento tan efectivo que puede lograr cambios notables en la personalidad"46. De ahí la importancia de comprender bien y reflejar correctamente a la persona ayudada para animar la comunicación y la auténtica relación de ayuda en profundidad.

Según C. T. Cochrane, estamos ante una condición necesaria, aunque no suficiente, del proceso terapéutico, y los autores discrepan sobre el modo de medirla. En 1961 Truax logró presentar su Escala de Empatía Correcta.

Ahora bien, no se trata de que el asesor tenga los mismos sentimientos que la persona ayudada, ni de ahogarse en su pozo, sino de ser sensible a sus sentimientos y de conocer al ser humano de tal manera que podamos captar los sentimientos que sólo "parcialmente revela". Por tanto, la empatía es la sensibilidad del counsellor a los sentimientos actuales de la persona ayudada y la facilidad verbal para comunicar su comprensión en un lenguaje adecuado a los sentimientos actuales de esa persona.

Cuando el nivel de empatía es bajo, el asesor ignora a la persona ayudada y sus sentimientos más obvios, se desinteresa de ella, la percibe sólo intelectualmente o adopta una actitud evaluadora ante ella. Cuando la empatía es alta, se captan con exactitud los sentimientos de la persona ayudada, sin equívocos ni dudas, y se perciben los sentimientos profundos en todo su contenido e intensidad.

En relación con la aceptación incondicional, se trata de aceptar sin condición alguna la experiencia del cliente, pero sobre todo su persona. Por lo

46 C. ROGERS, op. cit., p. 289. 
que hace a las escalas para medir la autenticidad y genuinidad, elaboradas por Carkhuff y otros, vale lo dicho para las de empatía. Según Carkhuff, en Helping and Human Relations, las tres condiciones básicas del conselling según Rogers, medidas por diversas escalas, "están, aunque en diferente grado, positivamente relacionadas con la efectividad terapéutica".

Finalmente, otros estudios acerca de las condiciones y cualidades del proceso de ayuda y su eficacia permiten afirmar, según Halkides y BarretLennard, que los clientes que más cambian en la relación terapéutica son los que perciben, desde el comienzo, "las condiciones de genuinidad, aceptación positiva incondicional o "cordialidad no-posesiva" y comprensión empática"47. Además, cuando la persona ayudada percibe, con claridad, esa cualidades, el cambio es más seguro, pero esa percepción depende también de "la experiencia del terapeuta".

Según los datos de un estudio de Truax y Carkhuff, las tres condiciones terapéuticas son importantes en la mejora del cliente, y sus índices de eficacia muy significativos. La puntuación para la empatía correcta sería el $77 \%$, para la aceptación incondicional el 73\%, y la genuinidad el $66 \% 48$. Otros estudios sugieren que, cuando estas cualidades son bajas, en el terapeuta, el paciente sufre pérdidas, en su crecimiento, mientras que cuando esas condiciones son altas "facilitan el cambio constructivo de personalidad".

En el estudio del Proyecto Esquizofrénico de Wiscosin, presentado por Rogers, la escala sobre la aceptación incondicional no se consideró fiable, pero la escala de congruencia o autenticidad apareció como muy importante en los procesos de mejora y lo mismo ocurrió con la escala de empatía. También el mejor nivel de los terapeutas, según Truax, fue importante para el mantenimiento del proceso de mejoría. Un estudio de la Clínica Psiquiátrica del Hospital John Hopkins, en 1966, reafirma, de nuevo, las tres constantes de Rogers, con algunas peculiaridades:

1.- Los pacientes que recibieron un mayor nivel de condiciones terapéuticas combinadas experimentaron una mejoría mayor. 2.- Muchos pacientes mejoraron en un $70 \%$, pero los que recibieron altos niveles de condiciones terapéuticas mejoraron hasta un $90 \%$. 3.- Pero, la "cordialidad noposesiva" de bajo nivel no mejoraba a los pacientes. Según Truax, Carkhuff y Kodman cuando dos cualidades están más altamente relacionadas

47 M. MARroquín, op. cit., p. 72. C. Rogers, op. cit., pp. 53-54.

48 M. MARROQUín, op. cit., p. 73. 
con el cambio y una tercera menos, el pronóstico debe basarse en las dos primeras.

Para terminar, conviene recordar que, según Truax y Carkhuff, la empatía, la cordialidad y la genuinidad, básicas en la terapia, también "son características de los encuentros humanos que cambian a la gente de una manera positiva".

\section{IV.1. PRIMER CONTRASTE CRÍTICO GLOBAL}

En este apartado vamos a ver algunas críticas al método de Rogers, acerca de sus presupuestos y de sus consecuencias, sus reparos y apoyos.

El profesor de psicología de la Universidad de Nueva York, P. Vitz, hace una dura crítica a la psicología humanista o de la autorrealización que conviene mencionar al estudiar la no directividad. Para el autor del prefacio, a la edición italiana, A. Manenti, no hay duda de que Vitz incita a examinar, con valentía y de cerca, los presupuestos de esta psicología, "en Italia más conocida como la teoría de Carl R. Rogers"49 .

Esta psicología propone una teoría muy positiva de la naturaleza humana que supone una tendencia del ser humano a realizarse, a privilegiar su experiencia personal, y a desarrollar, con plenitud, todas sus capacidades. Esta es una tendencia a la excelencia, a la libertad y la autonomía, compartida con Rogers por Maslow, Fromm, R. May, Adler, G. Allport, y, entre nosotros, en parte, por M. Yela. Al final, da la impresión que parece bastante bien a casi todas las escuelas psicológicas.

Por su parte, B. Giordani, se muestra extrañado de la tendencia mecanicista, pesimista y egocéntrica de la psicología no humanista, y muy contento con esta nueva antropología que irradia la gloria y la riqueza del "ser" y su altruismo frente al dominio del tener y su egoísmo ${ }^{50}$. Esta nueva concepción del hombre se inspira, según G. Allport y P. Tillich, en Bergson, Brentano, Stern, Kierkegard, Marcel y el existencialismo que toma al hombre como ser en camino, y se centra en la persona y la relación "yo-tú" descrita por Buber que lleva a la aceptación propia y del otro en su vida concreta y profunda.

49 P. C. VITZ, Psicologia e culto di sé, Dehoniane, Bologna 1987, p. 5. Trad. mía.

50 B. GIORDANI, La relación de ayuda: De Rogers a Carkhuff, p. 38. 
Ahora bien, esta psicología humanista, que parecía homologable al cristianismo, se descubre profundamente anticristiana porque incitaría al culto del hombre y del propio yo de forma casi religiosa o idolátrica. De ahí, el título original en inglés: Psychology as Religion que supone un humanismo secular fundado en el culto a sí mismo. Esta es la tesis del libro de Vitz que, según su autor, convertido al cristianismo episcopaliano, ha destruido muchas personas, familias y comunidades. Esta obra fue traducida al italiano, probablemente porque sus descripciones del yo interesaron a muchos psicólogos, asistentes sociales, pastores y educadores postmodernos.

Entonces, nuestro autor se centra en Fromm, Rogers, Maslow y R. May. A Fromm le acusa de rechazar la teoría de la agresividad de Freud, de describir un mundo idílico, donde el hombre habría superado el problema de la pobreza, y de que la base de la virtud es la bondad natural del hombre, el amor que irradia a todo, que es su verdadero poder con la afirmación del yo. Además, le acusa de considerar al cristianismo como "aliado del régimen", y de crear una idolatría donde el hombre es también Dios.

En cuanto a Rogers, Vitz le describe como alguien que, con su psicología no directiva, de aceptación incondicional, de empatía, de autenticidad, de expresión libre de los sentimientos, de cambio y crecimiento permanente, resuelve todos los problemas sin atenerse a valores ni a religión alguna porque la buena voluntad es una pura consecuencia objetiva del equilibrio del organismo.

En cuanto a Maslow, le presenta como el creador de la teoría de las necesidades humanas, de origen innato, que van de lo fisiológico, como alimentos y vestido, a la seguridad, pertenencia y amor, al respeto y buena reputación, hasta llegar a la plena realización que es el motivo supremo y fundamental. Así, cree Maslow que cuando uno la ha conseguido tiene una percepción más eficaz de la realidad y una relación más agradable con ella, se acepta mejor a sí mismo y a los demás, es espontáneo, tiene un yo autónomo e independiente, es creativo y capaz de experiencias culminantes, y una estructura democrática, igualitaria y humanizada. Es la creatividad inocente del niño, que vemos en científicos, políticos, humanistas, y escritores o artistas de primer nivel.

Vitz le reconoce a May su influencia existencialista, pero le reprocha su reivindicación de que "porque existo, tengo derecho a existir". Esto es muy revelador, porque, en el sistema democrático, uno es inocente, mientras no se demuestre lo contrario, mientras que, en el sistema no democrático, todo el mundo es culpable mientras no pruebe lo contrario, lo que rompe la presunción de inocencia. Esto es un desastre para la confianza y la convivencia. Vitz, sobre todo esto, no dice ni palabra. 
También le reprocha a May su optimismo existencialista que, según Vitz, es poco compatible con la angustia existencial humana. May, reforzaría, el componente existencialista de Rogers, en la experiencia personal del cliente. Y cita un pasaje donde éste ve a la persona, sobre todo, como sujeto y no como un objeto o caso clínico.

Por lo demás, esta buena nueva optimista y humanista pimpante se difundió por toda la sociedad occidental por medio de los grupos de ayuda en los que la confianza y la libertad de expresión facilitan una mayor aceptación de sí mismo y de los demás así como una mejor disposición al cambio. El análisis transaccional de E. Berne colaboró a la difusión de esta curiosa buena nueva con el "yo estoy bien, tú estás bien" de T. Harris.

Lo mismo harían la psicología de la asertividad, la liberación y la propia estima, de N. Branden, o la de la intimidación de R. J. Ringer. De igual modo, proceden los grupos EST o Seminarios Erhard de Entrenamiento, de corte muy revivalista, con total fe en la experiencia, la persona como "ser supremo" y su elección como nuevo dogma, pues, según Rogers: "yo soy aquel que elige" y "yo soy el que determina el valor de una experiencia para mí".

Este "yoísmo", devoto de sí mismo y del hombre, es ya una religión, propiciada por Fromm y Dewey, que J. Dixon llama "la dogmática del yo", donde todo está permitido. Pero, según Vitz, este planteamiento se opone al psicoanálisis, a los estudios de socio-biología y a la psicología que hablan de la agresividad destructiva humana.

No entraremos en estos argumentos con detalle, pero sí conviene recordar que el psicoanálisis acepta la agresividad humana como importante pero no como la condición más definitiva del ser humano, a no ser que se quiera pensar el instinto de muerte como un elemento fundamental de la herencia de Freud, lo que nunca ha estado claro.

Lo mismo ha de decirse de la socio-biología, puesto que tanto el hombre como los animales tienen como un especie de conciencia biológica o Mecanismo Desencadenador Innato (MDI) que impide la agresión mortal, excepto en situaciones muy especiales. Tanto K. Lorenz como Tinbergen como Leyhausen consideran que el mundo de los instintos es como un parlamento, coordinado por el MDI, que no sólo da origen a "bajos instintos", como muchos han pretendido, sino que también es capaz de producir a través del MDI y la biología, en palabras de Leyhausen: "un mundo superior de valores" 51 .

51 D. NATAL, "El instinto territorial y su orientación": Estudio Agustiniano 18 (1983) 365. 
En cuanto a la agresividad y la maldad de la naturaleza humana, bastantes antropólogos han sostenido siempre que primero es la cooperación y luego la agresividad y no al revés, como otros pretenden. No obstante, como fácilmente puede verse, se trata de una discusión interminable en la que cada uno se queda con la suya.

Así que, Vitz termina por preguntarse si somos tan buenos como se dice, y reconoce que la psicología humanista proclama la absoluta bondad humana a la vez que podemos ver cómo cada uno cree en sí mismo y defiende sus intereses. Así, Maslow declara "la naturaleza del hombre como esencialmente buena y no cautiva", Rogers habla de un "amor propio incondicional" y "la experiencia propia como lugar fundamental de valoración" mientras Fromm atribuye a la sociedad todos los males humanos.

Finalmente, Vitz ve en el existencialismo una gran contradicción entre su optimismo sobre el hombre y su crítica social, y mucha confusión en la definición del yo. Ahora bien, ser optimista no significa negar las dificultades de la vida ni desconocer la ambigüedad humana. Pero, con todo su frente crítico, el existencialismo ha visto al hombre como un ser capaz de plantearse y realizar verdaderos proyectos personales y sociales de crecimiento y cambio positivo.

Vitz cree que el "yoísta" se ama demasiado a sí mismo, es indulgente consigo, pone su creatividad en la base de todo, sin criterio ni valores, y así cae en un infantilismo que lleva a la egolatría: El hombre se convierte en un dios para el hombre, como dijo Feuerbach. El nuevo evangelio humanista ha sido predicado desde los púlpitos por Fosdick y Peale. De hecho, Fosdick predicaba el valor infinito de la persona, su gran potencial racional, su esperanza creadora y su amor, en perspectiva de cambio y progreso, como "el genio de cristianismo".

Vitz cree que el libro de Fosdick On Being a Real Person es la obra precursora de On Becoming a Person de Rogers. Así, para Fosdick, la plenitud de la persona y su integración, sería el equivalente actual de la salvación cristiana. Para Peale, el gran día de la vida de la persona es cuando comienza a realizarse, y, para eso, recomienda creer en sí mismo, en la propia capacidad, en la realización y las más grandes conquistas.

Para R. N. Sollod, que ha escrito sobre la terapia centrada en el cliente, Rogers no es un gran teórico, pero sí el leader de este nuevo gran movimiento, inspirado en J. Dewey, que todavía hoy llena USA. Rogers estaría muy influido por W. H. Kirlpatrick, según el cual, el crecimiento efectivo depende del ayudado y de su necesidad de crecer, no del terapeuta. Muy al final, de su trabajo, Vitz reconoce que, el ser plenamente aceptado, el amor incondicional al otro, la empatía y la sana confianza en sí mismo, son de ins- 
piración cristiana. Pero Rogers, según Vitz, caería en un narcisismo anticristiano muy creído en sí mismo.

Además, para Vitz, la confianza excesiva ha viciado la psicoterapia. Ya Freud se queja de ello: No se puede aceptar, a-críticamente, el relato del paciente. Ese tipo de confianza habría dañado, también, profundamente a la familia al convertir a los padres en el origen de todos los males como dominadores, represores, castradores, manipuladores y seductores, mientras se glorifica en todo al niño "intrínsecamente bueno y feliz", pero convertido en un tirano destructor. Así, la pura gratificación, individual, convierte a las personas en "átomos sociales narcisistas".

En lenguaje cristiano, estaríamos ante una idolatría que lleva al culto y a la adoración de sí mismo, de los propios deseos y de la propia voluntad, en palabras de $\mathrm{O}$. Baab, citadas por Vitz ${ }^{52}$. Es bueno ocuparse de sí mismo, amar a los otros y cuidarse, pero sin olvidar a Dios para que los ídolos de la egolatría, del poder, del dinero, del prestigio, y la cultura de la prepotencia y el narcisismo no lo inunden todo como ya describió Ch. Lasch.

De hecho, esta cultura ha llenado las instituciones burocráticas, asistenciales y educativas que empujan a las personas a hacer las cosas por sí mismas, sin más ni más. Así, las propuestas actuales sobre la persona o la sexualidad rechazan toda religión y se mueven al nivel de la pura biología. Y, la gente habla del propio yo, de la propia imagen y de la propia realización como habla del propio coche o de la propia úlcera.

Esto, cree Vitz, que como la empatía o la excesiva identificación con el otro, también, nos objetiviza, de modo que, así, el sujeto se convierte en objeto y el hombre libre en esclavo. De este modo, "la edad de la sensación" de la que habla $\mathrm{H}$. Hendin, es también la del egocentrismo para gozar lo más posible y comprometerse lo menos posible. Y, así, se llega al vacío del disfrutar, a la superficialidad y el teatro, la invulnerabilidad calculada, al control y la apatía de la vida, con desprecio del amor y la ternura.

Entonces, el hombre huye de sí mismo por el subjetivismo o el objetivismo sin que pueda rehacerse ni renacer, con nueva inocencia y nueva vida, como pide P. Ricoeur. Así, se cae en el desencanto, en le héroe estoico insensible o en el epicúreo divertido y alegre pero sin futuro. Pues, los propios creyentes han abandonado a los jóvenes, que huyen despavoridos de las iglesias, porque, según E. Becker, en vez de proponer el ideal cristiano del amor y la esperanza, presentan la "fútil épica de la posesión, de la

52 P. C. VITZ, op. cit., p. 101-2. 
ostentación y de la manipulación", como signo del Reino futuro, dando la espalda al milagro de la creación y a toda autenticidad y heroísmo.

Para terminar, decir que no hay que extrañarse demasiado de unas críticas tan duras a Rogers, ya que autores recientes lanzan también acusaciones contra él, como ideólogo de la Nueva Era o de creencias esotéricas que le habrían convertido en un nuevo "Ser Supremo" o en una especie de guru poco recomendable. Y así sentencia Jordi Segura: "Ya no estamos hablando de terapia: se trata de un intento más de concebir una nueva religión de la post-modernidad"53.

\section{1.1. UNA RESPUESTA A LAS CRÍTICAS}

Ahora bien, frente a todas estas críticas, Rogers volverá a insistir en que "el núcleo de la naturaleza humana es esencialmente positivo", y sus estratos más profundos "orientados hacia el progreso", y, por tanto, la persona tiene derecho a "sentir verdadero afecto" por sí misma. De hecho, Rogers cree que ambas hipótesis, han sido "confirmadas por mi experiencia".

Así, él piensa que esta visión es tan revolucionaria que no debe ser aceptada sin una "cuidadosa investigación". Es más, aunque superase con éxito esa prueba, sería difícil aceptarla. Como dice Rogers: "La religión, en particular la protestante, ha incorporado a nuestra cultura el concepto de que el hombre es básicamente un pecador, y su naturaleza pecaminosa sólo puede ser negada por algo parecido a un milagro" 54 .

Según Rogers, Freud abundó en esta dirección al decir que la naturaleza humana está determinada por instintos que expresados libremente llevarían a lo peor, a la irracionalidad y a la violencia: "el incesto, el asesinato y otros crímenes".

Pero según Maslow, la actitudes antisociales son producto de instintos básicos que buscan seguridad y pertenencia. Y para Montagu y los sociobiólogos, primero es la cooperación y luego la lucha. Es más, hay un principio de conciencia o mecanismo desencadenador innato (MDI) que, según Leyhausen, como hemos indicado, garantiza la protección de la vida, frente a la agresividad innata pues ambas se complementan.

53 J. SEgura, “Carl Rogers”, op. cit., p. 120.

54 C. ROGERS, op. cit., p. 90. 
Por eso, para Rogers, los sentimientos hostiles y antisociales no son lo más profundo de la naturaleza humana, pues la esencia de la vida humana y de nuestro organismo está "orientado hacia la socialización y la auto-conservación”. Es más, cuanto más profundizamos en nosotros mismos, menos cosas calamitosas y terribles encontramos, pues en el ser humano no hay bestia alguna sino sólo un hombre al que intentamos "poner en libertad". Al hacerlo, el hombre llega a ser lo que es, es decir: un organismo muy humano que funciona, plenamente, cuando descubre "su auténtico sí mismo".

De ahí que, la psicología humanista se haya concentrado en la atención más exquisita a la persona y sus cualidades, su dignidad y valor, que tiende a expresarse en un alto concepto del hombre y un gran respeto a todo lo humano, una verdadera confianza en la fuerza creativa de la persona y su capacidad de auto-realización, y una concepción dinámica, en su construcción y auto-determinación, con un gran sentido de unidad entre lo biológico y lo psicológico.

Así, se crearon los conceptos base de organismo, elaborado por Goldstein, para concretar esa unidad psicosomática humana y su dinamismo, con su poder de auto-realización, ya establecida por Max Scheler. Y, también, el tema central de percepción y campo perceptivo, como marco de referencia a partir del cual la persona dirige su vida y su conducta, la imagen de sí mismo que es la idea que tengo desde mi vida y de mi relación con los demás. Y, una idea sana del inconsciente como fuente de vida y potencialidad que desarrolla mi libertad de experiencia activa y positiva ${ }^{55}$.

Rogers trasladó al campo terapéutico esta antropología humanista, pues se dio cuenta de que, con frecuencia, la persona vive desesperadamente, pretendiendo ser un sí mismo falso o busca ser un personaje que realmente no es, como asegura Kierkegaard. Pues, cree que sin esta fachada no podrá sobrevivir. Por eso, dice Ortega, que el hombre es el único animal capaz de falsificarse a sí mismo. Pero cuando la persona se experimenta, en toda su riqueza, y se acepta y se descubre plenamente a sí misma, con todo su propio mundo, consigue llegar a ser lo que realmente es.

Entonces, la conciencia deja de desarrollar un sistema de pensamientos y sentimientos contradictorios, peligrosos e imprevisibles para albergar "un cúmulo de impulsos, sentimientos y pensamientos que se autogobiernan de manera satisfactoria, en ausencia del severo control hasta entonces ejercido"56. Así, la persona se siente dueña de su vida y confirmada en sus deci-

55 B. GIORDANI, La relación de ayuda: De Rogers a Carkhuff, pp. 48-60.

56 C. ROGERS, op. cit., p. 113. 
siones y se expresa tal como es, sin crear ningún personaje ajeno ni fachadas estáticas y eternas.

Y así aprende a vivir su vida, siempre con nuevos horizontes en una plenitud dinámica, sin temor alguno a cambiar. Entonces, el ser humano pasa de estar "prácticamente sano", a reconocer, poco a poco, los propios sentimientos, sin construcciones irreales, y a expresar sus propias vivencias con mayor libertad. La persona acepta las propias contradicciones y vislumbra su propia responsabilidad. Entonces, la experiencia se hace más flexible y auténtica con todas sus contradicciones, se distingue mejor entre los sentimientos y sus significados. $\mathrm{Y}$ esa experiencia se encara con mayor claridad y "la comunicación interna mejora y su bloqueo se reduce".

Del mismo modo, la congruencia, entre experiencia y percepción, aumenta notablemente y la persona se siente más libre y con una vivencia más plena. Los sentimientos fluyen con mayor claridad y riqueza. Se reducen los temores, se refuerza la confianza básica y la situación se experimenta como nueva, pues el hombre se hace dueño de sí mismo y de la propia vivencia y de su forma de ser.

En resumen, es la persona misma la que pasa de un primer momento, en que no ve los problemas ni la necesidad de cambiar, a otro segundo momento en el que descubre la génesis de los problemas y la propia responsabilidad en los mismos hasta asumir la necesidad de cambiar. Sólo así se puede llegar a alcanzar la meta vital más definitiva de la persona humana, que según S. Kierkegaard es: "ser la persona que uno realmente es" 57 . En esto consiste ser héroe, según Unamuno y Ortega: procurar ser uno mismo.

Entonces, uno deja de pensar en lo que debería ser pero que no es ni puede ser. Deja de utilizar máscaras y orientarse por expectativas ajenas, comienza a abrirse a la propia experiencia, con toda su complejidad e inmediatez, y toma la dirección de su vida para vivirla plenamente en cada momento. Crece, también, la aceptación de los demás y comienza uno también a confiar más en sí mismo y en sus capacidades, y a empeñarse, de forma más realista, en procurar ser él en plenitud de armonía.

Así, a pesar de todas las dificultades, para Rogers resulta profundamente estimulante, gratificante y muy significativo ver cómo el ser humano, que "disfruta de libertad interior, elige como la vida más satisfactoria, este proceso de llegar a ser". No es, desde luego, un proceso para cobardes, porque según Rogers, implica el coraje de "sumergirse de lleno en el torrente de la vida".

57 Ibid., p. 164. 
Se trata de una gran aventura, en la que la persona "descubre que se atreve a convertirse en sí mismo", apoyado por una relación interpersonal yo-tú, como dice M. Buber, que conduce al punto máximo de subjetividad personal y a unas relaciones sociales más profundas, más satisfactorias y más reales que nunca. Así se acerca la persona al estado de "máxima autenticidad" y de integración a todos los niveles.

\section{2. ALGUNAS DUDAS SOBRE LA EFICACIA DE LAS TERAPIAS}

Además de dudas y críticas globales, también se han suscitado bastantes interrogantes sobre la eficacia del counselling. Veamos cómo ha ocurrido y las respuestas ofrecidas.

Por lo general, la evaluación sobre los resultados de la psicoterapia y el counselling no suele ser bien aceptada y provoca resistencias. Se suele vivir, tranquilamente, de la confianza, más o menos difusa, en el éxito. Pero, poco a poco se va despertando de este sueño o letargo. Carkhuff, en su análisis del tema, se ha mostrado pesimista hasta afirmar que si el terapeuta funcionara en la vida como en la hora de entrevista, se convertiría pronto en paciente.

Hebb asegura que "no hay pruebas que demuestren que la psicoterapia es valiosa". Y Eysenck, después de revisar muchos estudios al respecto, y tratar de comprobar la influencia del psicoanálisis y otros métodos, en la persona ayudada, señala que los datos "no demuestran que la psicoterapia, ya freudiana o de otro tipo facilite la recuperación de los pacientes neuróticos"s8.

Levitt, a pesar de todo, en un estudio sobre los resultados de la psicoterapia en los niños asegura que, como ya Eysenck había señalado, los resultados "no prueban que la psicoterapia sea inútil".

No obstante, nuevos estudios de Barron, Leary, Truax y Carkhuff insisten en que se produce una mejoría similar entre los grupos tratados y los que no reciben tratamiento, especialmente, con terapeutas o consejeros de tipo medio. Con todo, Truax y Carkhuff ponen en duda la fiabilidad de los métodos usados por Eysenk. Nuevos estudios, de Cartwright y Vogel, mostraron que los pacientes de los terapeutas más experimentados tenían una mejoría mayor que los tratados por terapeutas menos expertos.

58 Ibid., p. 204. 
Un nuevo estudio de A. E. Bergin demostró que las personas de los grupos que reciben tratamiento, al contrario de los grupos de control, tienen una "marcada mejoría o marcado empeoramiento". Todos esto demuestra, según Carkhuff, que los resultados del counselling o la psicoterapia no pueden considerarse como neutros sino que pueden tener consecuencias "positivas o negativas". Como asegura Carkhuff, en una de sus obras más conocidas: "Realmente producimos impacto" 59.

Esto llevó a Carkhuff a afirmar que: $1^{\circ}$.- Ciertos tratamientos, aún no especificados, son efectivos. $2^{\circ}$.- El grupo experimental varía mas que el de control, y, $3^{\circ}$.- El counselling y la psicoterapia producen cambios positivos o negativos en la personalidad del paciente. Estas conclusiones pueden extenderse a la relación padre-hijo, profesor-estudiante y a cualquier otra relación interpersonal.

Rogers, también, estudió si las terapias habían producido cambios significativos y si se debían a la terapia misma o a otros factores. Estos estudios, realizados con personas que podrían considerarse típicos del Counseling Center de la Universidad de Chicago, llevaron a la conclusión de que se producen cambios positivos, en la "auto-percepción del cliente", en las características y la estructura de su personalidad, en la adaptación, la integración y la madurez de la persona ayudada, y una coincidencia cada vez mayor "entre el sí mismo real y el ideal para todo el grupo".

Ese cambio, que se produce con la terapia es significativamente superior al que "se produjo en el grupo de control". Así, las personas se comprenden mejor a sí mismas, confían más en sus posibilidades, están más cómodas consigo mismas y con los demás, se sienten menos culpables y resentidas, más seguras y libres, no necesitan ocultarse nada a sí mismas y expresan más libremente sus experiencias positivas o negativas. Según Rogers, esto basta para invalidar las afirmaciones de Hebb y Eysenck 60 .

De hecho, el método de Rogers incorporó, desde el principio, la investigación del proceso de cambio. Así, por ejemplo, se vio que el cambio positivo del ayudado lleva a que el sujeto se evalúe a sí mismo más desde la propia experiencia que desde la ajena. Y que la persona entrenada en terapia de estrés se maneje también mejor, y con mayor autonomía, en la vida normal.

Del mismo modo, se comprobó que las respuestas del ayudante, que "reflejan sentimientos", aumenta la capacidad de exploración y la profun-

59 M. MARroQuín, op. cit., p. 37.

60 C. GIORDANI, op. cit., pp. 206, 214. 
didad de experiencia de la persona ayudada mientras que los juicios de valor o interpretativos la paralizan. Las investigaciones de Rogers y Dymond han confirmado también que la psicoterapia mejora la propia imagen, la integración personal y social, así como la responsabilidad y la satisfacción personal 61 .

Además, la terapia ayuda al sujeto a reconstruir su personalidad, de ese modo se volverá más original, personal y expresivo, más emprendedor y más realista, más confiado en sí mismo. Se valorará más positivamente, será menos reprimido y poseerá una conducta más madura, socializada y adaptada, afrontará mejor el estrés, y su estructura personal se acercará más a una persona sana, integrada y que vive en plenitud.

También se ha demostrado que la terapia mejora la madurez emocional, de modo que, tanto el individuo como los que le conocen, lo expresan con una puntuación más alta en la Escala de Madurez Emocional de Willoughby. Igualmente, cuando la persona mejora, en la terapia, "la conducta diaria" del individuo gana en madurez.

También se ha comprobado que cuando la relación terapéutica cumple bien las condiciones necesarias y suficientes de Rogers, es más efectiva. Esto se observa desde el principio del proceso, sobre todo cuando el ayudante es "auténtico y cálidamente humano" y "sólo le interesa comprender cada uno de los sentimientos" de la persona ayudada. La correlación entre el nivel de condiciones positivas ofrecidas por el terapeuta, y el nivel de progreso del paciente, ha sido certificada por los estudios de Rogers, Gendlin, Kiesler\& Truax, Aspy, Gardner y Patterson.

Lo mismo puede decirse del bajo nivel de cualidades fundamentales del consejero y su influencia negativa en el paciente. Por eso, es necesario que el ayudante se implique en su preparación personal y técnica, en actitudes y destrezas, para confiar en el dinamismo de la fuerza constructiva humana, dar a la experiencia la máxima autoridad, para saber escucharse y aceptarse a sí mismo y comprender al otro sin juzgarlo.

Finalmente, hoy día ya nadie duda de que la terapia ha mostrado una eficacia extrema e incluso, escandalosa, como está muy bien probado en su capacidad provocar cambios y condicionamientos en la personalidad de los individuos, como ha demostrado Skinner en sus estudios y en su novela Walden Dos.

Lo mismo nos dice Rogers, en relación a la selección de personal, publicidad del consumo, grupos de trabajo en la industria, la educación y el ejér-

\footnotetext{
61 Ibid., p. 229.
} 
cito, cambios de la personalidad y estado de ánimo de la persona, ya sean constructivos o destructivos, etc. Por eso, como ha dicho Bertalanffy, además de las amenazas de "la tecnología física" están las de "la tecnología psicológica"62.

Así que hoy albergamos muy pocas dudas sobre la eficacia de la terapia psicológica. De hecho, sabemos cómo destruir la personalidad de un ser humano, por medio de sistemas de privación, y cómo suscitar relaciones de apego a un zapato viejo en la conducta de un pato. Por eso, el poder de la psicología no parece estar en discusión, pero sí lo está el que la usemos para crear o para destruir personas. R. Oppenheimer pensaba que el poder de la psicología podría constituir un problema más grave que el de la física.

Por tanto, es evidente que hoy, un cierto control sobre los recursos humanos se puede ejercer y habrá de ejercerse. Skinner le atribuye unos efectos benévolos. Huxley los utiliza con buena intención, en sus novelas, y resulta una pesadilla, mientras Orwell describe un uso malintencionado de estos sistemas de poder al servicio de la dictadura.

Ahora bien, mientras Skinner insiste en aplicar "la ciencia del hombre a los problemas humanos", a Rogers, esta aplicación le "inspira un fuerte desagrado", pues cree que destruirá la persona espontánea, libre y responsable, que ha intentado promover.

Rogers cree que, en toda práctica científica, hay una decisión previa, de valores como autorrealización, libertad y sociedad abierta, que hay que tomar y que no pertenece estrictamente al campo de la ciencia. Como dice J. Dewey: "La ciencia ha forjado su camino liberando -no suprimiendo- los elementos de la variabilidad, la invención, la innovación y la creación original en los individuos"63. La decisión es nuestra.

\section{3. LA APUESTA POR LA NO DIRECTIVIDAD Y REPAROS A LA MISMA}

La no directividad ha sido defendida por Rogers, por su colaboradora G. M. Kinget, y con algunos reparos, por Mariano Yela. Veamos este proceso.

62 C. Rogers, Ibid., pp. 320, 325.

63 C. Rogers, Ibid., p. 344. Sobre esta discusión puede verse: F. Torralba, “¿Podemos mejorar las generaciones futuras?": Bioética \& Debat. Tribuna abierta del Instituto Borja de Bioética 37 (2004), pp. 1-4. 
En su Prólogo, a la edición española de la obra de Rogers y Kinget, sobre psicoterapia y relaciones humanas que es una teoría y práctica de la terapia no directiva, Mariano Yela hace algunas observaciones que me parece importante recoger en este momento.

En primer lugar, Yela afirma que Rogers es una rara avis, un creador que piensa por su cuenta, sin esconderse ni en técnicas ni doctrinas, y que hace camino al andar como cantaba Machado. Así crea: "el consejo nodirectivo; la psicoterapia centrada en el cliente. Yo diría: la psicoterapia de la libertad"64.

Por eso, para Rogers, la persona es un agente positivo que acude al psicólogo con voluntad de ser y de crecer. Este, ni le dirige ni le somete a una técnica ni le clasifica ni le interpreta. El psicólogo se ofrece al otro como persona, le acepta incondicionalmente, hace todo por comprenderle con empatía y le presenta su autenticidad. Así, se arriesgan y se comprometen los dos a encontrarse o a perderse con la libertad de Rogers.

Además, Rogers acepta al otro incondicionalmente y la persona ayudada siente que esto es así. Este es el acto fundamental de la terapia, según M. Yela, un "acto de fe y de amor incondicionales", por ambas partes. Al fin, la relación terapéutica se logra por la comprensión empática. El psicólogo se esfuerza por comprender lo que significa para la persona la propia experiencia, y no la juzga ni censura ni aprueba, ni hace nada que lleve al otro a enmascararse.

La persona ayudada está sola consigo misma, con sus coherencias e incoherencias, frente a otra persona que con sus propias contradicciones también trata de ser él mismo. Así, cada uno va encontrándose "en sus propias manos y con su libertad". Y, de este modo, se atreve a explorarse, a rememorar y liberarse de tensiones reprimidas, a entrever nuevas posibilidades y a admitirse a sí mismo, a hacerse más libre y disponer más libremente de sí. Esta es la esencia de Rogers, que cada uno asimilará, a su modo, para poder liberarse y ayudar a liberar.

Para Yela, todas las terapias tratan de ser aliento de libertad, pero la de Rogers "es sólo psicoterapia de la libertad". De ahí, la terminología negativa de su método: "no-directivo, no-técnico, no-interpretativo, no diagnóstico". Pues, nadie puede liberar a nadie y cada uno ha de liberarse a sí mismo. Por eso, el terapeuta no dirige.

Según M. Yela, hay dirección pero una dirección común y mutua cada uno desde su originalidad no canjeable. Hay técnica, pero la técnica que eli-

\footnotetext{
${ }^{64}$ M. Yela, Prólogo a C. Rogers - G. MARIAn KInget, Psicoterapia y Relaciones humanas. Teoría y práctica de la terapia no directiva, Alfaguara, Madrid-Barcelona 1971, t. I, p. VII.
} 
mina la tentación de quedarse en ella. También hay un cierto diagnóstico pero no se basa en él como catálogo del otro que esconde su libertad ni es determinante de futuro ni de pasado. De hecho, no se bucea en el inconsciente sino que es la persona la que ha de buscar y explorar libremente, "según lo necesite y se atreva, en su propia realidad".

La ciencia es, para Rogers, una parte de la vida y para la vida de las personas. Y, como la educación ha de ser liberadora. Por eso, cada cual debe enseñarse a sí mismo lo que vale la pena aprender. No se enseña a otro cosa alguna, desde fuera, sólo se puede enseñar a otro desde su intimidad libre. Como dice Raúl Rodríguez: las ventanas sólo se abren desde dentro...

Así, nosotros, hoy no debemos pensar como Rogers, dice Yela, sino que tenemos la oportunidad de pensar con él. Cada uno hemos de ejercer nuestra autenticidad desde nuestro fondo vital propio y nuestra energía libre y creadora. Pero eso no quiere decir que todo sea fácil, ni se pueda siempre evitar que, la terapia y la vida, sea "una penosa reconstrucción de sí mismo".

En este sentido, Yela cree que Rogers podría insistir algo más en la finitud, la temporalidad, la falta y otros temas existencialistas para no caer en un "optimismo naturalista" que es ya cosa del pasado. Por eso, según Yela, no es extraño que a Rogers se le haya tachado de angelismo, dado que el fondo biológico no es pura disponibilidad, como sabe muy bien Rogers, y muestra la bioquímica, la neuropatología y la psiquiatría de estados y procesos timo-páticos. De hecho, el cuerpo humano es también enfermedad, dolor, fatiga, y no sólo alegría y salud. Y nuestros ánimos vitales son también muy contrapuestos: bienestar y desgana, energía y desfallecimiento, etc, etc.

De ahí que, para Yela, la prevención de Rogers contra "la técnica, la dirección y el dignóstico" es, "quizá, exagerada". Así lo advertiría, Max Pagès, gran experto en el tema de la no directividad, "con palabras tan justas como generosas": "La forma propia de compromiso afectivo del terapeuta con el paciente, es justamente su actividad teórico-técnica... Esta es, ciertamente, la "prueba de amor" que él da a su paciente, y que es mucho más exigente que cualquier expansión emocional" 65 . No obstante, parece bien cierto que Rogers, sin devaluar la técnica, confía mucho en el amor. O como lo dijo V. Frankl: "Todavía más, mediante su amor la persona que ama posibilita al amado que manifieste sus potencias"66.

65 Ibid., p. XIX. Traducción mía.

66 V. FRANKL, El hombre en busca de sentido. El análisis existencial y la conciencia espiritual del ser humano. Paidós, Barcelona 1999, p. 110. 
Ahora bien, la gran aportación de Rogers, al respecto, según Yela, es desenmascarar y rechazar la técnica como "medio de poseer al otro". Pero quizá le faltó insistir un poco más en que la técnica es una gran invención humana positiva e inevitable que no puede ser usada ni como disfraz propio ni degradada a instrumento de dominio. Y, que entraña, también, un momento fundamental de donación personal a la libertad del otro que es como la entendía Rogers. Lo mismo pasa, según Yela, con el diagnóstico y la dirección. Pues al hombre no se le libera como a una cosa ni con cosa alguna, sino con la entrega amorosa de la propia intimidad en auténtica libertad. En ese sentido, según Yela, todos nos "dirigimos" unos a otros, todos nos influimos mutuamente.

La personalidad fascinante de Rogers es aleccionadora a este respecto y tampoco él podía saltar sobre su propia sombra. Así, para Yela: "La psicoterapia es inevitablemente técnica y directiva". Pero Rogers ha desmitificado la técnica y ha denunciado el carácter enajenante y negativo de su veneración quasi mágica en la sociedad actual. Y nos ha recordado, seriamente, que no se puede liberar al hombre desde fuera sino en el encuentro personal y desde su libre apropiación de cada una de las posibilidades que le ofrece la propia vida. Tal sería "el sentido de la psicoterapia de la libertad", para Yela.

G. Marian Kinget, que escribe con Rogers la obra: Psicoterapia $y$ Relaciones humanas, sobre teoría y práctica de la terapia no directiva, dedica la I ${ }^{a}$ parte de esa obra precisamente al método no directivo. Ahí, nos dice que la concepción no directiva históricamente está justifica pero que desde el punto de vista de la realidad viva del pensamiento "esta noción está claramente superada". Además, asegura que esa noción no es la fundamental del método, pero, "se impuso, por decirlo así, a los primeros observadores de ese modo nuevo de diálogo reparador que es la psicoterapia"67.

Lo que se desprendía claramente de las entrevistas grabadas, ya entonces, era la ausencia de "diferentes formas de dirección", como preguntas, consejos e interpretaciones, consideradas entonces parte integrante del papel del terapeuta. Además, todo esto, en Rogers, respondía a valores que él consideraba decisivos. Por eso, "cuando le invitaron a publicar su teoría la calificó sencillamente de no directiva".

Además, se comprobó que los que no obtenían buenos resultados con este método, lo aplicaban "sin ningún compromiso personal", como si fueran una "pantalla neutra" al viejo estilo psicoanalítico. Esto hizo pensar a

$$
\text { t. I, p. } 8 .
$$

${ }^{67}$ G. M. KINGET, "El método no directivo", en C. Rogers - G. MARIAN KINGET, op. cit., 
Rogers que lo más importante del nuevo método no era tanto la ausencia de directividad como la presencia del terapeuta, con unas actitudes profundas para con el cliente y una nueva idea de las relaciones humanas.

Así, el cliente debe ser el centro del proceso. El terapeuta se sumerge con él, en su vida, en una actitud de empatía y aceptación incondicional. Por eso, la nueva terapia tomó el nombre de psicoterapia centrada en el cliente. Entonces, se pregunta G. M. Kinget, ¿porqué ha persistido la expresión de terapia "no directiva"?

Pues, de un lado, porque la expresión inglesa client-centered no es fácil de traducir aunque el método sea bien conocido, y de otro, porque bastantes terapeutas se han fijado más en el método no directivo que en las actitudes más importantes de fondo. Pero, quizá hay que atribuirlo, también, a que la expresión "no directivo" es muy clara y tiene toda la pinta de ser "un programa" con el que muchos se identifican.

Pero sobre todo, según Kinget, la idea de no directividad produjo una verdadera sacudida, todo un terremoto, en el campo de la terapia, un verdadero "shock" ideológico, frente a todo lo que se había hecho antes, que puso a muchos de los nervios. Algo muy parecido a cuando Freud lanzó el psicoanálisis y sus teorías de la sexualidad. En este caso, no ha habido un rechazo vehemente, como a las teorías de Freud, sino una "resistencia pasiva" pero mucho más persistente.

Al fin, Freud fue aceptado, por la voz de la experiencia, pero la necesidad de dominar o ser dominado que tenemos los humanos hizo que la resistencia, a la "no directividad", fuera mucho más consistente que la necesidad "de liberar y de ser libres". Pues, la libertad humana es un don pero sobre todo una conquista que requiere mucho esfuerzo. Así, la "no directividad" es como una fórmula indeleble de oposición o mentís: ¡No es verdad! o ¡Es imposible! enderezar a un individuo neurótico y en conflicto "sin emplear un diagnóstico y una dirección"68.

Otros, insisten en aseverar que el método de Rogers no es aplicable a las relaciones humanas normales. En resumen, el método rogeriano es "demasiado revolucionario para ser recibido en el plano de la acción sin provocar resistencias". Incluso, entre muchos liberales y demócratas persiste el anhelo jerárquico que se esconde bajo la etiqueta de "competencia" o "responsabilidad" profesional y que, a veces, solapa un deseo muy inconsciente de "ascendiente y dominación" en el ayudante y una tendencia al mínimo esfuerzo en el ayudado.

68 Ibid., pp.128-19. 
Algunas veces, no directividad se confunde con permisividad total, sin darse demasiado cuenta de que la conducta del ayudado está en gran parte determinada por el ayudante. Externamente, incluso, ambas actitudes, se parecen mucho pero, realmente, no tienen nada que ver. Porque la permisividad se inspira en la indiferencia o en una tolerancia más bien despectiva mientras que la no directividad se fundamenta en una actitud "incondicionalmente positiva".

La no directividad ofrece a la persona ayudada comprensión, calor y respeto total, mientras que la permisividad total le puede dar al aconsejado una impresión de abandono que refuerza su desesperanza y ambivalencia. Por lo demás, la alternancia entre intervención y permisividad total confunde al asesorado que no sabrá a qué atenerse. Finalmente, la no directividad tampoco es inactividad pero sí tiene mucho que ver con la idea de no ser un intervencionista intempestivo que no respeta en nada el desarrollo del otro.

También conviene advertir, que es muy frecuente que los terapeutas se declaren no directivos o, al menos, no se definan como directivos, pero el estudio de grabaciones de entrevistas y los relatos de estas, que aparecen en las obras de psicoterapia, son "un testimonio irrefutable de que estos terapeutas se portan de un modo manifiestamente directivo, aunque ellos pretendan lo contrario"69. Negar esto sería, para Kinget, confundir directividad con coerción o con "tomar las riendas de la vida cotidiana del cliente", lo que ningún terapeuta avisado se atreverá a hacer hoy. Estas conclusiones quedan refrendadas por la supervisión de los terapeutas en formación, que suelen ser inconscientes de la profunda influencia que "ejercen sobre el cliente". No se dan cuenta que una sugerencia del ayudante es para muchos ayudados un consejo, o que las preguntas del terapeuta son, para otros, indicadores de un itinerario mental, ni que sus manifestaciones de aprobación o desaprobación son vallas infranqueables para un individuo "ávido de consejos y direcciones".

Por lo demás, la no directividad se refiere de forma muy especial a la abstención de juicios de valor sobre la vida de la persona ayudada, pero eso no significa falta de criterio acerca de sus experiencias. Incluso, muchos personas solicitan el juicio del terapeuta, su aprobación o sus críticas, y quedan contrariados cuando éste no accede a sus peticiones. Esa es, precisamente, una indicación muy clara de la inseguridad e inmadurez que "impide a tales sujetos tener un funcionamiento adecuado".

\footnotetext{
69 Ibid., p. 22.
} 
Pero además, propiciar esa "asistencia", dificulta enormemente el proceso de saneamiento y liberación, que debería aportar la terapia que quiere, precisamente, desarrollar la capacidad de "auto-evaluación y auto-dirección". Ahora bien, en ocasiones, según Kinget, expresar la propia opinión sobre un hecho o una acción es una medida "indicada e incluso necesaria". Pero sin olvidar nunca que el papel fundamental del ayudante es promover el juicio autónomo, la iniciativa personal y la maduración de criterios anclados en la experiencia de la persona ayudada.

A veces, también se dice que "la no dirección no existe". Pero, según Kinget, es cierto que "la no dirección existe". Y hay abundantes testimonios grabados de esto. Pero es cierto, que no todo lo que se designa o práctica bajo ese lema, de "no directivo", tiene esa garantía. No es fácil sustraerse a nuestra tendencia a dirigir, sobre todo cuando estamos ante personas con dificultades, en la aventura de la vida, que para muchos, incluidos nosotros mismos, parecen evidentes y trasparentes.

Ahora bien, no directividad no es igual que vacío de todo. Así, para Kinget, toda psicoterapia está, inevitablemente y deliberadamente, "orientada en una cierta dirección" que sería el crecimiento y la auto-realización de la persona. Y, cuando el ayudante, conversa con el ayudado, selecciona, quiera o no, ideas, sentimientos y recuerdos. Además, la simple presencia de la persona tiene efectos sobre la otra, aunque aquélla no tenga intención alguna de influir o dirigir, según sea el estado mental o emocional de la persona afectada.

Es más, dado que todo lo que el hombre percibe lo percibe con significación, incluso las realidades más materiales o físicas "llevan consigo una cierta dirección". Y esto, lo sabe muy bien la publicidad comercial, y su lenguaje de objetos. En el caso de la terapia de Rogers, el hecho de que la persona ayudada permanezca sentada frente al ayudante y no acostada, como en el psicoanálisis, es todo un tratado completo sobre el sentido de esta terapia entre iguales y del método a seguir. Desde este punto de vista, toda situación humana implica dirección o potencial de la misma. Del mismo modo: "Toda situación psicoterapéutica está, pues, impregnada de dirección -es decir, de significación orientada- por muy no directiva que sea la actitud del terapeuta"70.

De ahí que la no directividad no consiste en abandonar a la persona a sí misma sino en confiar en su propia capacidad, para comprenderse y resolver sus problemas, eficazmente, en un contexto de relaciones humanas posi-

70 Ibid., p. 27. 
tivo, favorable a su construcción del yo, que confía en su tendencia a la actualización y realización propia como un elemento fundamentalmente enriquecedor de la relación de ayuda. Es preciso, también, creer en la libertad de experiencia de sus emociones, exigencias y deseos y en la expresión confiada de la comprensión que la persona tiene de sí misma.

Esa atmósfera, muy propia de la relación de ayuda debe llevarnos también a una consideración positiva incondicional de la persona, afirmándola en una seguridad, no tutelada ni dependiente, que anularía sus recursos, sino en la que desarrolla su autonomía y estimula su capacidad de autodeterminación, ayudándole a reconocer sus recursos y propiciar su emergencia así como su capacidad para afrontar sus dificultades y resolverlas con sus propios medios, centrados en la persona del ayudado y no en el ayudante. Por eso, hay que encuadrar la entrevista dando el protagonismo a la persona ayudada y no a las explicaciones, respuestas o técnicas del terapeuta, insiste Kinget.

La no directividad supone también una aptitud cálida con la persona, que es una relación cordial, pero que no debe ser un calor demasiado intenso que quemaría a la otra persona, con transferencias y contra-transferencias, y comprometería el proceso de ayuda y "el resultado terapéutico". Además, como ya hemos visto, el ayudante debe ser profundamente empático no simpático, auténtico, emocionalmente maduro, con un sentido positivo de la vida y del ser humano, centrado en la persona, comprensivo, tolerante que acepta incondicionalmente a la persona ayudada.

Como lo resume Rogers: si soy capaz de crear una relación auténtica y trasparente, con una acogida cálida de los sentimientos del otro, aunque sean diferentes a los míos, y lo vivo desde una capacidad de "ver el mundo y el yo del cliente tal como los ve él mismo", entonces la persona se vuelve capaz de comprender, por sí misma, los aspectos de su vida que antes negaba a su conciencia, evolucionará cada vez más hacia el tipo de persona que desea ser, funcionará con una facilidad y confianza cada vez mayores, se realizará como persona, es decir como un ser único que piensa y actúa por sí mismo y se vuelve "capaz de abordar los problemas de la vida de un modo adecuado y con menos gasto emocional".

Por otra parte, al presentar la obra de Rogers sobre Psicoterapia centrada en el cliente, L. Carmichael, asegura que en ella se hace una clara exposición de los procedimientos para ayudar a los individuos, aconsejados, para que "logren por sí mismos adaptaciones nuevas y más efectivas de su personalidad", así como de las implicaciones vitales del "consejo no-directivo" en una gran cantidad de campos. Y se afirma que esta obra "es una exposición madura de los puntos de vista no-directivos en el consejo y la 
terapia"71. Rogers dice, que en este proceso, el individuo está "luchando por ser él mismo, y sin embargo mortalmente temeroso de serlo".

Este método de Rogers encuentra sus raíces en la terapia de Otto Rank y el grupo de Filadelfia, y en la influencia de Kirlpatrick discípulo de Dewey. Ya en 1940 presenta nuestro autor su método en Consejo y psicoterapia, que pronto fue rotulado como "consejo no-directivo", al que siguió Manual de Consejo no-directivo, que supone una gran confianza en la persona, para poder ayudarla. Pues, si fracasa la actitud de respeto a la dignidad de la persona y su derecho a dirigir su vida, la técnicas valen poco.

El ayudante solamente podrá ser no-directivo si el respeto al otro y la confianza en la capacidad de la persona, "para dirigirse a sí misma”, está profundamente arraigado en su vida. Si el ayudante solamente cree en sí mismo, en su gran responsabilidad, pero no en el ayudado, "confunde al cliente y se derrota a sí mismo". Entonces, se dedicará a diagnosticar, en vez de a escuchar a la persona ayudada.

En palabras de Raskin, la no-directividad es más una meta que un logro ya conseguido, y consiste en que el consejero trate de meterse en el pellejo del otro, participando activamente en sus sentimientos, mediante "la atención más intensa, continua y activa, a los sentimientos del otro, hasta el punto de excluir todo otro tipo de atención"72.

Este centrarse en el cliente, al ir pensando, sintiendo y explorando con él, sin confundirse con él, es una característica decisiva "de la terapia nodirectiva" que define muy bien al terapeuta no directivo. Sólo así se puede "adoptar el marco de referencia del cliente" y llegar a una verdadera empatía. Así, el centro de la relación de ayuda es el cliente mismo y la confianza en sus posibilidades para volverle a sí mismo, pues: "el papel del consejero era el de volverme en mí".

De este modo, la persona ayudada recupera su propio y verdadero yo con su propia libertad. Pues, en la terapia no-directiva la persona se siente bien escuchada y aceptada, siente que tiene una buena comunicación con el ayudante que le ayuda a ser ella misma con su empatía. Entonces, asistimos, con enorme respeto, a la lucha del hombre por la recuperación de su propia identidad y su propia capacidad de autodeterminación. "Desde este punto de vista, la expectativa del consejero de que "usted puede autodirigirse", constituye el estímulo social al cual responde el cliente"73.

\footnotetext{
71 C. Rogers, Psicoterapia centrada en el cliente, Paidós, Barcelona $1997^{3}$, p. 10.

72 Ibid., 40.

73 Ibid., p. 57.
} 
Para algunos esa seguridad no está muy justificada, pero para otros muchos, la acción responsable que surge de la persona es mucho más "efectiva que la acción dirigida". Así, se ha comprobado, también, en los grupos de trabajo, que tienen posibilidad de iniciativa que promueve la "facultad de responsabilidad", la auto-dirección y la confianza. Ahí se descubre que la impaciencia estrangula los esfuerzos, y se reafirma la idea de que cuando la persona ve aceptado su punto de vista el conflicto comienza a resolverse.

Es la persona la que ha de resolver sus problemas, como responsable primero y verdadero de su propia situación, no un experto que la sustituye, aunque le apoye para comprender mejor su situación y ser más honesta consigo misma. El ayudado es el único que puede ahondar en su situación, entrar en ella de veras, aceptarla y orientarla de nuevo, en diálogo consigo mismo, sin intrusión del consejero, para que pueda aceptar plenamente su vida y permitir que "su experiencia le exprese su propio sentido". Así, la terapia es una experiencia y una intuición propia de la persona, y "no una experiencia acerca de la persona". Es la persona la que se ha metido en el problema, y la que debe salir del problema, no el terapeuta.

En ese sentido, uno de los principios importantes del ayudante, según Roberto Álvarez, es "fomentar la auto-eficacia". Para A. Rocamora: "Mediante la "relación de ayuda" facilitamos al otro la posibilidad de reactivar sus propias capacidades y restablecer la armonía consigo mismo y con los demás. No damos soluciones hechas, ni imponemos una dirección. Mas bien hacemos descubrir los jalones del camino que conducirán a la persona en conflicto a la meta de su equilibrio emocional y social" 74 .

Por otra parte, si alguien pregunta hacia dónde se dirige y el interrogado le confirma que hacia el Norte, no quiere decir que éste le ha impulsado "hacia esa dirección". Pues, cuando el ayudante asume el punto de vista del ayudado no hay nada que objetar a su experiencia del camino. De hecho, la responsabilidad se mantiene en el campo del ayudado y, entonces, este se siente como en su propia casa, en todo caso y en todas partes, porque todas sus respuestas forman parte de su sistema de adaptación y realización vital y no de un manual de diagnóstico. Eso no quiere decir que la nueva perspectiva y el nuevo camino que conduce a ser plenamente uno mismo, no sea dificultoso, como en el caso de aconsejados que son "agresivamente dependientes". Pero, incluso, ante las transferencias, el ayudante "trata de comprender y aceptar".

74 A. Rocamora, Counselling por Teléfono, (Apuntes), Centro de Humanización de la Salud, Madrid 2006, 9. Remarcado mío. 
Según Rogers, su método es tan poco directivo que, al día de hoy, aún no sabemos, a ciencia cierta, en qué consiste, realmente, su terapia. La impresión actual es que se trata de "un movimiento desde los síntomas hacia el sí-mismo". Otro aspecto patente es que reemplaza el material del pasado por el presente. Hay, también, un cambio en la percepción y la actitud hacia sí mismo. Es una actitud más positiva en todo, para con el propio conocimiento y los propios sentimientos, con una mayor "aceptación de sí mismo", como persona digna de respeto y en buena relación con los otros, basada en la propia experiencia, con mayor espontaneidad, con más libertad para explorar su vida, vivir para sí y "amarse a sí mismo" con criterio vital propio ${ }^{75}$.

Otros indicadores podrían ser: mayor libertad y seguridad en la relación, importancia decisiva de los sentimientos, de la vida emocional y su libre manifestación, menor represión en todo, menor auto-rechazo, más capacidad de control con menor ansiedad, menos conductas defensivas, mayor capacidad para beber de la propia experiencia y de la parte más vital de sí mismo, una mayor disposición al cambio, más sentido constructivo, una integración vital y social más agradable, y más objetividad en todo.

\section{LA CRÍTICA DE CARKHUFF Y LA FORMACIÓN DEL CONSE- JERO Y SUS DESTREZAS PARA EL COUNSELLING}

A la vista de las críticas y los reparos, al método creado por Rogers, y otros problemas que encuentra su discípulo independiente, R. R. Carkhuff, este se propone afinar el método. Así, aunque respeta las tres condiciones básicas, señaladas por Rogers, Carkhuff introduce nuevas variables y algunos procedimientos, no tan considerados por Rogers, con una insistencia especial en la importancia del terapeuta, que modifican la idea global de una no directividad, absoluta e incondicional, tan propiciada por Rogers.

Según Marroquín, todos los estudios sugieren que hay diferente eficacia, de los terapeutas, aunque todos hayan expresado los mismos niveles en las tres condiciones básicas de Rogers. Así, esas condiciones serían, ciertamente, necesarias pero no suficientes en el proceso terapéutico.

De ahí que Carkhuff, muy cercano a la sensibilidad humanística, valora positivamente la centralidad de la persona, y la confianza en ella y en su

75 C. Rogers, Psicoterapia, 129-130. 
experiencia, según la propuesta de Rogers, pero como recogen, tanto Marroquín como Giordani y Alemany, Carkhuff propone a Rogers abrir un poco más su posición a otros "ingredientes de la efectividad terapéutica" ", cosa que Rogers no acepta.

Entonces, Carkhuff decide hacer su propio camino y matizar algunas de la condiciones básicas de Rogers, incluida la idea de persona para considerarla más en su relación social. También se preocupa más de la eficacia. Y, por lo que se refiere a los diversos pasos del proceso, mantiene gran similitud con Rogers en la auto-exploración, pero introduce elementos del psicoanálisis y otros en la auto-comprensión, y al iniciar a la acción toma principios de la teoría del aprendizaje y de la modificación de la conducta.

Carkhuff, también, admite que su teoría cambiará con el tiempo, como hizo Rogers, ante nuevas experiencias que le harán cambiar de nuevo, e insiste en promover el cambio constructivo del comportamiento para ayudar al ser humano "a descubrir nuevos aspectos y nuevas posibilidades en sí mismo, y lo estimula a utilizar sus propios recursos", como dice J. Fuster, buen conocedor del método de Carkhuff. Esta terapia se extiende a la vida normal, como una enseñanza global más importante, y el paciente pasa a llamarse "ayudado" o "asesorado" y el terapeuta "ayudante" o "asesor".

Carkhuff, sin abandonar la psicología humanista, modifica también la visión, demasiado optimista, de Rogers respecto a la persona humana. Pero sin caer en la visión pesimista, sobre el hombre como ser "reactivo", del conductismo y el psicoanálisis, Carkhuff defiende una concepción del hombre más neutral en la que éste es a la vez un ser activo y reactivo. Y así, "rechaza el optimismo predicado por los pioneros de la Tercera Fuerza e integra de forma significativa el método no-directivo"77.

Para Carkhuff, el hombre no es ni bueno ni malo, depende de la experiencia recibida. Admite una tendencia del hombre a la realización de sí mismo, como una unidad creativa orientada a su fin, capaz de avivar y llevar adelante un proceso de desarrollo, pero niega que eso tenga su origen "en un organismo intrínsecamente bueno". Se trataría, más bien, de un dinamismo que recibe estímulos de realización positiva o negativa, "por el contacto con el ambiente". Por tanto, Carkhuff cree que es necesario introducir nuevas variables "capaces de promover el desarrollo con ritmo intenso, estimulando activamente los recursos de la persona". Así, Carkhuff, nos dice Giordani, se define a sí mismo como un "humanista militante".

\footnotetext{
76 B. GIORDANI, La relación de ayuda: De Rogers a Carkhuff, pp. 14 y 123-4. En esta presentación, de la teoría de Carkhuff, seguimos muy de cerca a Giordani.

77 Ibid., p. 130.
} 
Por otra parte, Carkhuff piensa que la persona es capaz de conservar y promover su crecimiento y expansión, sea ayudante o ayudado. Y que si se cree libre lo será y viceversa, pero es necesario, también, apoyar la creación de disposiciones internas constructivas. Carkhuff no cree en la libertad como mera ausencia de condicionamientos externos, sino como un conjunto de capacidades concretas que permiten a la persona afrontar sus situaciones vitales.

En definitiva, la persona plenamente realizada, para Rogers, sería la que tiene una verdadera apertura a la experiencia en todos los niveles, un funcionamiento existencial, en la que fluyen los sentimientos de una vida plena y en cambio, y una confianza en el organismo, como guía competente para una respuesta orgánica profunda. Pero, para Carkhuff, como recoge Giordani, la persona total se desarrolla armoniosamente, en la dimensión física, afectiva e intelectual, por "la adquisición siempre más amplia que el individuo hace en relación con las destrezas físicas, afectivas e intelectuales".

Este es un proceso largo de aprendizaje ineludible. Por eso, Carkhuff considera que la corriente rogeriana se pierde en un idealismo seudo-democrático que toma por humanismo la falta de estímulo a la persona a dar lo mejor de sí misma o a dejar al hombre "abandonado a sí mismo, e invitado a hacer aquello que desea".

Así, el proceso terapéutico de Rogers, basado sobre todo en la confianza, subraya: -la importancia de la experiencia de las propias capacidades, -de una relación afectiva de aceptación plena, del amor a uno mismo, -de los descubrimientos de los propios recursos constructivos, y -la solidaridad con el propio organismo y la propia experiencia, como guía interior digna de confianza y capaz de orientar comportamientos eficaces y gratificantes.

Pero, Carkhuff destaca la incidencia que la enseñanza positiva tiene sobre la persona para afrontar de manera constructiva las diversas situaciones que presenta la vida, y que tiene como objetivos fundamentales: -comprender lo que hay dentro de mí, -comprender lo que me falta,-comprender la necesidad de actuar, -valorar la propia situación, y -no exigir menos de lo que el individuo puede hacer, resume Giordani.

Esto quiere decir que, dado el camino recorrido, el mensaje central de Carkhuff, en sus obras sobre el proceso de ayuda y las relaciones humanas, consiste ahora: "en no aceptar que el individuo funcione en un nivel más bajo del que podría funcionar"78. Aquí, Carkhuff se da cuenta que se separa de Rogers y la psicología humanista, y lo acepta tranquilamente. No obs-

78 Ibid., p. 142. 
tante, conviene recordar lo que, en la misma dirección, advertía Maslow: si nos exigimos por debajo de nuestras posibilidades nunca seremos felices pues dejaremos sin realizar muchas de nuestras cualidades.

Así pues, entre Rogers y Carkhuff, hay semejanzas y diferencias bien conocidas. Carkhuff reconoce que Rogers fue un gran pionero pero hay que seguir avanzando. Entonces Carkhuff introduce nuevas destrezas, confía más en los asesores, le pide a la persona ayudada un nuevo compromiso con su desarrollo, quiere llegar a toda la sociedad, por la enseñanza, como el mejor tratamiento, y con una apertura permanente al cambio para conseguir métodos más eficaces y para seguir creciendo.

Carkhuff reconoce como válidas las hipótesis de Rogers, pero las declara insuficientes, "y sigue un camino que, superando las técnicas no-directivas", se orienta, claramente, a la acción. Y "aún teniendo en cuenta los principios de la no-directividad y de la centralidad del cliente, propone superarlos, eliminando el dualismo directividad/ no-directividad para sustituirlo con el concepto de continuum entre estos dos extremos"79.

Esa es la razón por la que Carkhuff comenzó a hablar de la existencia de otras nuevas variables a tener en cuenta, como: la Concreción o Especificación, la Confrontación y la Inmediatez o Relación del Momento, y la Auto-revelación.

Pero, además, Carkhuff subraya de una manera muy fuerte la influencia especial del consejero, que es positiva cuando funciona a alto nivel y negativa cuando funciona a nivel bajo. Y, por eso, le pide al counsellor que se esfuerce en adquirir una idea positiva de la persona humana, un conocimiento adecuado de sí mismo, que le impida influir negativamente en el asesorado, ya sea en su percepción o en sus sentimientos. Además, es muy importante que el asesor procure conseguir una madurez sana y realista que le lleve a aceptarse como es, para poder aceptar con satisfacción al otro, y una disposición interior hetero-céntrica que le lleve a centrarse en el otro en vez de caer en un egocentrismo que le impediría empatizar con la persona ayudada.

En efecto, cuando el perfil del orientador es bajo, la relación de ayuda se vuelve ineficaz, según Carkhuff y Berenson. De acuerdo con las investigaciones de Aspy y Handlock, los profesores se suelen mantenerse en el nivel 2, que casi no aporta nada, recuerda E. Repetto. Los asesores de tipo existencialista y centrados en el cliente suelen tener mejor nivel que los meramente conductistas, y, así, son más efectivos.

${ }^{79}$ Ibid., p. 152. 
En este sentido, Carkhuff establece, además, una escala de evaluación de la relación asesor-asesorado con cinco niveles. En el nivel $1^{\circ}$, el asesor no cuida al cliente y así no le puede ayudar. En el $2^{\circ}$ nivel el asesor presta atención al asesorado, le escucha y le atiende, pero apenas se implica. En el nivel $3^{\circ}$, el asesor da una respuesta intercambiable, en contenido y sentimientos, a lo que el asesorado expresa. En el $4^{\circ}$ nivel, el ayudante personaliza lo que el ayudado comunica, promueve la comprensión de la situación en relación a la meta a la que el ayudado tiende. $Y$ en el $5^{\circ}$ nivel, el ayudante inicia un programa de acción con el ayudado y estudia con él los pasos a dar.

En resumen, se podría decir que en los dos primeros niveles apenas hay verdadero proceso de relación de ayuda, en el nivel $3^{\circ}$ se daría un intercambio provechoso, una respuesta intercambiable, del ayudado al ayudante y viceversa, que permite iniciar el proceso verdadero, y a partir del nivel $4^{\circ}$, el proceso mejora y profundiza la relación de ayuda que llega a su plenitud en el nivel $5^{\circ}$.

Este análisis valdría tanto para las tres actitudes fundamentales de Rogers, como para medir los procesos de exploración, de auto-comprensión y de iniciación a la acción de la persona ayudada. Así, los niveles 4 y 5 de la aceptación positiva supone un hondo respeto que propicia la emergencia de la persona del ayudado en toda su plenitud. En el nivel 4 y 5 de autentici$d a d$, el counsellor es muy libre, espontáneo y claro, es en profundidad él mismo, abierto a toda experiencia e invita a una relación más honda al aconsejado.

Ahora bien, al hablar de la escala de empatía de Carkhuff, al exponer el nivel $4^{\circ}$, Giordani afirma lo siguiente: "El terapeuta completa significativamente los contenidos y/o los sentimientos expresados por el cliente". Aquí, el ayudante refleja lo expuesto por el ayudado e incluso hace explícito, lo expresado por el ayudado de manera confusa o ambigua, y baja a niveles más profundos. De este modo, el ayudante hace ver al ayudado que está con él y que sintoniza plenamente su misma onda.

Ahora bien, ¿no se podría decir que aquí hay algo más que mera no directividad?... Giordani afirma que: "el terapeuta precede al cliente, va por delante de él". No obstante, habrá que proceder con enorme respeto y cautela para no asustar ni sorprender al ayudado, y no hacer diagnósticos ni adelantar soluciones ni interpretar ni juzgar nada y proceder con gran sensibilidad ante la experiencia y los sentimientos del ayudado.

Además, como ya hemos mencionado, Carkhuff introduce nuevas variables para una nueva terapia. Así, habla de la concreción o especificidad por la que el ayudante apoya al ayudado para expresar de forma directa, completa y fluida, aquí y ahora, los sentimientos, actitudes y experiencias 
propias, y para ayudarle "a centrarse cada vez más en sí mismo". Según los estudios de Truax y Carkhuff, de 1964, la concreción es "la dimensión que contribuía más eficazmente a la orientación, más aún que la comprensión empática, la aceptación positiva y la genuinidad" 80 .

Esta característica obliga al counsellor a no ser abstracto ni racionalizar, y a ser "más exacto en la comprensión del cliente", de modo que éste pueda expresar mejor el núcleo de sus problemas y conflictos emocionales, ayudándole a pensar con preguntas abiertas pero concretas. Según Egan, la concreción ayuda a encontrarse con la intensidad y densidad que canaliza las energías del ayudado y le conduce a la acción, evitando los juegos y cortinas de humo de las que puede servirse para escapar al compromiso de cambio.

Pero, si ayudante y ayudado caen en el nivel más bajo de concreción, se pierden en generalidades y abstracciones y no entran, para nada, a discutir los asuntos relevantes. En el nivel más alto, el ayudante ayuda al ayudado a explorarse a sí mismo y sus sentimientos de modo que logre ver su situación personal con sus problemas específicos y se determine a planificar de modo realista las acciones a seguir.

Además, Carkhuff incita a la confrontación que, según Repetto, refiere a la experiencia del orientador que observa en el orientado, en su conducta o exploración, discrepancias o contradicciones verbales o para-verbales. Esto obliga al orientador a enfrentar al ayudado con esas contradicciones, y a auto-confrontarse también. La confrontación es una variable "activa" del terapeuta, dice Giordani, igual que la "relación del momento" o "inmediatez", es una variable, por la que "el terapeuta precede al cliente y actúa por iniciativa propia"81. Si el orientador afronta esas discrepancias sería un buen nivel, pero si, además, lo hace con gran sensibilidad y empatía, sería lo más deseable.

La confrontación ha sido muy discutida. Mientras unos, como Carkhuff y Berenson, la consideran útil e importante, otros, como los rogerianos más puros, creen que es ineficaz e incluso contraproducente como dicen Kaul o Bednar. A este respecto, conviene recordar que la confrontación no puede ser un desahogo del ayudante contra el ayudado sino que debe nacer de una auténtica empatía.

Ahora bien, como lleva consigo un cierto quitar las máscaras a la persona, tanto de sus cortinas de humo como de sus potencialidades, hay que

80 E. REPETTO, op. cit., p. 192.

81 B. GIORDANI, La relación de ayuda: De Rogers a Carkhuff, p. 194. 
usarla muy al final y con mucha delicadeza, "en un clima de profunda comprensión empática", cuando estamos ante un problema importante y crítico, que no es reconocido por el ayudado o éste lo distorsiona con una percepción falsa de la situación que vicia la misma relación terapéutica.

En este sentido, según Marroquín, hay que ser conscientes y tener en cuenta también que: "El cliente sabe, por una parte, que necesita ayuda y busca a alguien más fuerte y más experto que él mismo para que se la proporcione; por otra parte, sin embargo, desea derrotar a esa misma persona y someterla a los diversos "juegos”, más o menos neuróticos que se reflejan entre ambos. Esta situación concreta es la que el consejero debe confrontar sin dejarse atrapar por los juegos del cliente, después de haberlos entendido en profundidad" 82 .

De esta manera, la confrontación puede referirse a la realidad de la experiencia de cada cual, y ser realmente didáctica porque completa la información del asesorado, o de fortaleza porque subraya sus posibilidades o puntos fuertes, o de debilidad, que insiste en los aspectos oscuros de la persona, o de exhortación a la acción, que pone una palabra de aliento y ánimo en el proceso final. Así, la confrontación tiende positivamente a que la persona reconozca sus recursos, asuma su responsabilidad y no eluda los problemas.

Por lo demás, la confrontación se correlaciona bien con la mayoría de las otras variables fundamentales de la relación de ayuda cuando el nivel de los asesores es alto. De este modo, el ayudante llama la atención del cliente sobre sus contradicciones o las pone en evidencia y le confronta positivamente con ellas. Pero los asesores de perfil bajo insisten en confrontar la debilidad, o en ir contra el ayudado o en pasar de él, o en prestarle poca atención o en dejarle con sus contradicciones.

La confrontación, según Carkhuf produce una cierta crisis de tensión y angustia con desorganización de un falso sentido de seguridad. Por eso, la persona ayudada puede atacar al ayudante. Y, según Egan, eso lo hace o bien directamente, o tratando de que cambie sus puntos de vista, o devaluando la importancia del tema a tratar, o haciéndose la víctima o sometiéndose aparentemente.

Todos estos juegos pueden anular el valor de la confrontación y la relación de ayuda, si el counsellor cae en ellos. Pero no hay que tener miedo a la confrontación porque el counselling no debe ser un mero "laisser faire" ni un pura charla entre amigos.

82 M. MARROQUín, op. cit., p. 83. 
En cuanto a la inmediatez o relación al momento, parece que une la empatía y la confrontación, y lleva al orientado a conocerse mejor a sí mismo, aquí y ahora, en su relación con le orientador y "en relación con lo más íntimo de sí", para que pueda "funcionar en el nivel más alto de su realización personal". Así, la persona ayudada sabe que el asesor conoce, real y plenamente, lo que él le dice, y su comunicación es un intercambio de vida, de sentimientos, de la íntima realidad personal, "con el respeto profundo de tocar lo intangible: la mismidad del otro en su propia mismidad" 83 . Así, se le ayuda al asesorado a mirarse, primero, a sí mismo y después a los demás sin escudarse en sus dificultades externas.

Según Carkhuff, la inmediatez difiere de la transferencia psicoanalítica porque considera positiva la acción del terapeuta, no una mera relación de respuesta o rebeldía, y no está unida a ninguna teoría de la personalidad que reduzca la experiencia a un tema fundamental como en el psicoanálisis.

Pero, ciertamente, "es un modo privilegiado de afrontar e intentar resolver las relaciones transferenciales faltas de autenticidad"84. Así, la relación de inmediatez entrena para vivir, con autenticidad y trasparencia, todas las relaciones normales de la vida. En ese sentido, también, el proceso de ayuda, según Sullivan, tiende a controlar la ansiedad que pone en peligro nuestra autoestima, nos hace vulnerables en exceso, y nos impide entrar en nosotros mismos y comunicarnos plenamente con los demás.

Por lo que hace a la escala de niveles de la inmediatez, en el nivel 1 y 2 , el ayudante no tiene apenas en cuenta el contenido ni la carga afectiva que suscita la relación de ayuda. En el nivel 3, el ayudante está dispuesto a interpretar lo que pasa en la relación pero recoge y refleja poco lo que la comunicación del ayudado dice que ocurre entre él y el ayudante. En el nivel 4, el orientador expresa lo que está pasando entre ellos, pero si, además, acierta plenamente, en la forma apropiada de explicitarla, estamos en el nivel 5.

Una última variable nueva que propone Carkhuff es la auto-manifestación que es como un paso más en el desarrollo de la autenticidad genuina. No obstante, algunos la consideran positiva y otros negativa. Debe estar plenamente al servicio del proceso terapéutico y del bien de la persona ayudada.

Por eso, es necesario que el consejero se auto-manifieste de una forma apropiada, y en el momento adecuado para no convertirse a sí mismo en el centro de la relación de ayuda. Se trata de ser auténtico, no de esconderse

83 Ibid., p. 199.

84 J. C. BERMEJo, Apuntes de relación de ayuda, p. 94. 
ni de llamar la atención con cualquier cosa. Según Carkhuff, el consejero de alto nivel se manifiesta con naturalidad, el de bajo nivel tiende a esconderse. Por lo general, no conviene auto-manifestarse demasiado pronto porque distraería a la persona ayudada, pero tampoco esconder la propia vida porque eso indicaría falta de autenticidad y distorsionaría el proceso.

Así, en el nivel 1 y 2, de la escala de Carkhuff para esta variable, el ayudante se muestra como distante y no toma la iniciativa de manifestarse positivamente. En el nivel 3, el ayudante se muestra dispuesto a comunicar informaciones que interesan al ayudado pero lo hace de forma algo vaga y parcial. En el nivel 4, el ayudante toma la iniciativa de comunicar al cliente ideas, actitudes, experiencias que interesan al ayudado en relación con sus problemas. Y en el nivel 5, el counsellor comunica libremente experiencias personales que interesan al ayudado. Y si tiene algún sentimiento negativo, con el ayudado, lo utiliza de forma constructiva e intenta buscar sus causas.

\section{1. LA NUEVA PROPUESTA DE CARKHUFF}

Hacia 1980, Carkhuff elabora y madura un modelo muy centrado en las destrezas del terapeuta, que éste debe asimilar, y que consisten en aprender a escuchar, responder, personalizar, e iniciar, que ayudan al asesorado a implicarse en el proceso de cambio, a auto-explorarse, comprenderse y a iniciarse en la acción, que implican un cierto cambio en la no directividad.

Así, con la disposición y la técnica de escuchar se trata de generar confianza con una auténtica acogida, gentil y amable, con una verdadera atención al ayudado en ambiente distendido. Así se le ayuda a explorar y comprender su situación y a comprometerse con el cambio. Para eso, conviene comunicar la propia disponibilidad, crear una atmósfera tranquila, con un espacio material apropiado, donde el ayudante esté cercano, al mismo nivel, inclinado hacia el cliente con contacto frecuente de la mirada, donde el silencio no sea una tensión, el llanto sea acogido, el secreto profesional algo sagrado, y las pautas de los encuentros pactadas y conocidas por ayudante y ayudado ${ }^{85}$.

Es necesario también observar tanto el lenguaje verbal como el no verbal, el estado de ánimo del ayudado, en el que se enmarcan los contenidos

85 B. GIORDANI, La relación de ayuda: De Rogers a Carkhuff, pp. 224-4; 174-6. 
y los sentimientos, así como el aspecto exterior, la intensidad afectiva y su disposición real a la relación de ayuda.

Escuchar significa, también, prestar atención psicológica para asimilar y recordar, lo más fielmente posible, de modo abierto y orientado, lo que el otro nos está diciendo, y recoger con exactitud su mensaje. De este modo, ayudamos a las personas a comprenderse mejor y a establecer nuevas conexiones en su experiencia de tal forma que cada uno pueda ver cómo se percibe a sí mismo y cómo ve a los demás, qué significa para él su situación actual, cómo la valora, a qué grado de libertad ha llegado y cuáles son capacidades, sus valores y entusiasmos. Pues, como dice Giordani, la persona ayudada sólo nos escuchará, realmente, cuando él sienta también que le hemos escuchado a fondo.

En cuanto a la destreza de responder, indica un tipo de intervención por la que el ayudante devuelve al ayudado lo que ha percibido en su mensaje verbal o no verbal. Así, el ayudante anima al ayudado a auto-explorarse y auto-revelarse, a ver sus dificultades y los recursos de que dispone así como a plantearse el compromiso a asumir. El counsellor consigue esto cuando reformula los contenidos, recoge los sentimientos, que manifiesta el aconsejado, y le muestra la conexión entre ambos. Y así le ofrece, a la persona ayudada, una "respuesta intercambiable", con su misma intensidad, que le anima a seguir su tarea ${ }^{86}$.

Al responder a los contenidos, el ayudante hace algo parecido a lo que Rogers llama "reiteración", por la que devolvemos al ayudado lo que él nos comunica. Pero no se trata de una pura charla de amigos sino que el ayudante asegura al ayudado que ha sido bien comprendido, le confirma su atención y su interés por él, y le facilita la entrada en su mundo interior. Aquí, el ayudante no tiene que hacer interpretaciones ni juicios ni conclusiones ni "adivinaciones" propias sino que le toca repetir lo dicho por el ayudado. Puede hacerlo con palabras como: "tú me dices que...", o bien: "me estás diciendo...".

Para responder a los sentimientos, hay que hacer algo parecido a lo que Rogers llama "reflejo del sentimiento". Esta destreza consiste en recoger los movimientos interiores del ánimo de la persona, verbalizados o no. Para poder empatizar con ellos hay que preguntarse "¿cómo me sentiría yo en su caso?", y para acercarse mejor al ayudado conviene emplear las fórmulas: “¿tengo la impresión de que te sientes...?”, o “¿quizá te sientes o quizá esto te hace sentir...?", o "¿me pregunto cómo te puedes sentir con lo que me

86 Ibid., p. 231. 
has dicho?". Si se produjesen silencios en el proceso no hay que ponerse nerviosos, porque los silencios son muy necesarios a la introspección y la confrontación.

Finalmente, hay que intentar responder al sentimiento y al contenido, tratando de conectarlos bien, pues muchas personas encuentran una gran dificultad para unirlos. Además, la toma de conciencia de los motivos del estado de ánimo moderan mucho o disipan la ansiedad y facilitan la gestión y control de la misma. Si no es fácil encontrar las causas concretas de una situación emocional, entonces conviene ir a una búsqueda más precisa y preguntar por el quién, el qué, el dónde, cuándo, cómo y porqué.

Hay que tener en cuenta que el tema del sentimiento no es "puro sentimentalismo", sino algo muy importante en la vida y la relación de ayuda, pues como dice J. C. Bermejo en sintonía con L. Cian: "una persona necesitada de ayuda, lo primero que espera no es una solución a su dificultad, sino la comprensión y acogida del modo más íntimo de su forma de vivir las propias dificultades, y que se traduce en estados de ánimo"87.

Hacia finales de los años de 1970, Carkhuff, con otros dos colaboradores suyos, introduce, explícitamente, la destreza de la personalización. Sería como un paso intermedio entre responder e iniciar. Con esta destreza se pone al ayudado en primer lugar y en primera persona para que pueda enfrentarse mejor a sus responsabilidades. Así la persona ayudada se convierte en la figura central y principal del cuadro y del panorama, para que pueda asumir su problema como propio, no como algo extraño o debido a causas externas, y comprometerse decididamente en su solución.

La personalización puede provocar rechazo, porque con esa empatía personalizada tratamos de que la persona comprenda "el nivel en el que él se encuentra presente, en relación con el que quiere llegar o al que tiene que llegar". Y así, vamos un poco "por encima de lo que el cliente nos comuni$c a$ ". Por eso hay que prepararla. Carkhuff aconseja hacerlo hasta con 6 respuestas intercambiables, Giordani cree que serán bastantes más.

Una buena norma es no pedirle al cliente una responsabilidad que se ve que él no está preparado para asumir. Un primer paso a dar es personalizar el significado para que la persona pueda comprenderse y ver cuál es su compromiso con su situación concreta. Entonces dejará de echar la culpa a

87 J. C. BERMEJO, "La relación de ayuda como instrumento de humanización", en J. C. Bermejo (ed.), Salir de la noche. Por una enfermería humanizada, Sal Terrae, Santander 1999, p. 77. Hoy sabemos muy bien que los sentimientos proceden de lo más profundo del ser humano, como ha explicado magistralmente: A. DAMAsio, En busca de Spinoza. Neurobiología de la emoción y los sentimientos, Crítica, Barcelona 2005. 
agentes externos y asumirá su realidad personal inmediata. El lenguaje apropiado del terapeuta para ayudar al aconsejado a personalizar ha de ser: "Tu te sientes...porque tú...". Si no obstante hubiera o persistiera el rechazo, el ayudante ha de aceptarlo, pues debe respetar la perspectiva del ayudado.

Un segundo paso es personalizar el problema, para ayudar a la persona a ver su tema en términos de responsabilidad personal, para que deje de echar la culpa a los demás o eludir el problema. Para suscitar esa conciencia se sugiere la fórmula: "Tú te sientes... porque tú no...". El ayudante debe tratar de percibir o encontrar la carencia o dificultad principal, en conductas concretas y no en puras intenciones o motivaciones. Si no se estuviera seguro y no se pudiera formular, concretamente, se puede preguntar a la persona hasta qué punto puede él ser responsable de su situación.

Si la persona rechaza la propuesta o le produce sentimientos negativos hay que volver a las respuestas intercambiables.

Un tercer paso es personalizar el nuevo sentimiento que trata de recoger el estado de ánimo en que se encuentra el ayudado a estas alturas del proceso. Hay que intentar centrar el tema en la persona ayudada para que pueda expresarlo en primera persona, como: "me siento sólo", y no: "estoy enfadado porque mi mujer trabaja mucho". Las palabras adecuadas para ayudar a personalizar el sentimiento son: "Tú te sientes... porque tú no"... El ayudante debe preguntarse por "el sentimiento principal" que le trasmite el ayudado, y tratar de concretar lo que el aconsejado le trasmite en abstracto. $\mathrm{Si}$ el asesorado rechaza la propuesta hay que volver a las respuestas intercambiables hasta que se le vea dispuesto a retomar el camino.

Finalmente, se ha de intentar personalizar la meta. Se trata de ayudar a la persona aconsejada a mirar en la dirección en que desea moverse y señalar la meta del cambio adecuado. Este paso suele ser más fácil que los anteriores porque la persona ayudada ya ha aceptado su responsabilidad, en su situación y, generalmente, se muestra deseosa de hacer y conseguir el cambio.

Pues, como es sabido, lo que la persona no ha conseguido cambiar, es el problema, y la meta a perseguir es la solución. Pero no siempre es fácil identificar la meta. La fórmula para personalizar la meta es: "Tú te sientes... porque tú no... y deseas...". El ayudante debe preguntarse por aquello que el ayudado no consigue hacer y querría hacer o cómo ayudar a la persona a resolver su problema, dice Giordani.

Cuando el ayudado acepta bien la meta propuesta, podemos pasar a la última fase del proceso o las destrezas de iniciar. Es la fase de superación de la situación no deseable o fase ascendente o de la salida del pozo. Carkhuff ha dedicado muchos estudios a esta fase y en su escrito, en colaboración con 
W. A. Anthony, le dedica tres capítulos por uno que dedica a las destrezas de responder y personalizar.

Para Carkhuff, el grado de eficacia de un terapeuta viene definido, especialmente, por esta destreza de promover un programa de acción eficaz. Como recoge Giordani: "...la eficiencia de un terapeuta está en función de sus destrezas afectivas e interpersonales y de sus destrezas de programación en diversos sectores de su especialización"88.

Ahora bien, la destreza de iniciar, tiene tres momentos: definición de la meta, pasos a dar para conseguir el objetivo y hacer el camino propuesto, y apoyo a la persona ayudada en el proceso. Iniciar significa encontrar una orientación vital, capaz de dar significado positivo a la propia vida, y proponer un objetivo concreto y constructivo, a conseguir, con un programa de acción significativo, verificable y realista.

Es una meta y un programa que se han de madurar con el aconsejado mediante las variables situacionales que nos indican el quién, qué cosa, dónde, cómo, cuándo y por qué de la acción concreta. Así, se le ayuda al ayudado a pensar y a puntualizar mejor los factores que conducen a la meta. Esa definición concreta de la meta se convierte en el objetivo hacia el cual el ayudado intenta moverse mirando a sus capacidades concretas y a sus propias cualidades.

Aquí, se trata de explorar las posibilidades y alternativas para encontrar la solución y superar la situación, de identificar y precisar las preferencias expresadas por la persona ayudada, y de llegar a una conclusión final eligiendo la forma operativa más adaptada a las cualidades y posibilidades del aconsejado. Así, se programan, también, los pasos concretos a dar por la persona ayudada, se le apoya para pensar a corto y a medio plazo la meta, con sus ventajas y dificultades, se hace un balance de las decisiones a tomar o ya tomadas, se analizan los objetivos concretos, se fortalece el compromiso de cambio y se preparan y desarrollan los escenarios deseados.

En todo este proceso, según Roberto Álvarez, no hay que ser ni muy directivo, como si aprovechando la buena disposición, al cambio, de la persona ayudada, "le voy a decir lo que tiene que hacer". Pero tampoco hay que dejar al ayudado sólo y a su aire, colgado en el vacío y sin ofrecerle alternativas, pues: "Si el enfoque no directivo se mantiene: 'Entonces estás considerando qué es lo que puedes hacer'. Confundirás al paciente" 89.

\footnotetext{
88 B. GIORDANI, La relación de ayuda: De Rogers a Carkhuff, p. 247.

89 R. Álvarez, De la Segunda a la Tercera fase del Counselling, (Apuntes), Centro de Humanización de la Salud, Madrid 2005, p. 30.
} 
Por el contrario, en el clima de diálogo, de autenticidad, de empatía y confianza, del counselling, hay que ir buscando y programando, junto con el aconsejado, una serie de pasos concretos que éste necesita dar. Así, hay que "ayudar a pensar" para procurar encontrar, unos pasos "principales" que son como metas intermedias y algunos pequeños pasos llamados "secundarios" que ayudan a conseguir los primeros.

Ahora, se trata ya de concretar el modo de llevar a cabo o ejecutar el programa. Se ha de mantener con claridad el deseo de alcanzar la meta y buscar los pasos adecuados que conduzcan a ella sin perderse en el camino con objetivos extraños. Así, la persona ayudada debe mantenerse alerta en el camino hacia la meta. De hecho, las personas que fallan en su objetivo hacia la meta, con frecuencia, lo hacen ya en el primer paso, por falta de confianza o de adecuada capacidad. Con los pasos secundarios, la persona aconsejada mantiene y alimenta los hitos principales del camino hacia la meta.

En todo este proceso, el ayudante debe apoyar a la persona ayudada, prestándole toda su atención y respondiendo a sus estados de ánimo, con el fin de mantener vivo su compromiso de cambio. Para eso, es necesario el uso de refuerzos para mantener vivo al aconsejado en este proceso final. Es frecuente, que las personas decidan cambiar, incluso que lleguen a elegir la forma concreta de hacerlo, pero luego, por distintos motivos, la persona se cansa, pierde el sentido de los compromisos que se vuelven pesados y la meta se hace lejana y poco atractiva, de modo que se volatiliza.

Aquí ya se pueden elegir y acordar "premios" y "castigos" que la persona ayudada se aplicará por sí mismo. Por otra parte, conocemos bien, por propia experiencia, la tendencia humana a disculpar los fallos o debilidades. En esto, el ayudante debe ser objetivo y no "colaborar". Como resume Giordani: 1) No acudir a la entrevista es no acudir a la entrevista, independientemente de los factores que lo hayan "facilitado". 2) Cuando el ayudado no cumple el compromiso asumido, entonces es una persona que no alcanza la meta, independientemente de los motivos, y quizá es incapaz de alcanzarla. 3) La tendencia a racionalizar las ausencias tiende siempre a fijarse y a aumentar ${ }^{90}$.

Para terminar este apartado, recordar, una vez más, que en toda relación de ayuda, es importante que, conforme avanza la entrevista, los niveles de condiciones terapéuticas del counsellor se desarrollen también, tanto con vistas a la autoexploración como en dirección a la acción. Pues, el grado

90 B. GIORDANI, La relación de ayuda: De Rogers a Carkhuff, pp. 251-2. 
de compromiso del ayudante está directamente correlacionado con el grado de compromiso del ayudado "en el desarrollo y el cambio de su personalidad".

En este sentido, también, es decisivo, el compromiso del aconsejado, primero con el ayudante y luego con autonomía propia, aunque, según Piaget, hay asesorados que mantienen un alto nivel de autoexploración y auto-experiencia aunque el nivel del asesor sea más bajo. Pero eso no es lo normal.

Así, tanto la condiciones propuestas por Rogers como las sugeridas por Carkhuff tienen una gran influencia en el proceso de cambio, en el que la relación personal es decisiva. Para E. Repetto: "es la persona del orientador la que primariamente ayuda, modela y refuerza el cambio constructivo de la personalidad del orientando" 1 . Si él no es una persona "integrada y creativa", que siente la responsabilidad de hacerse a sí mismo y ayudar a los demás a realizarse, es difícil que haya cambios ni sea posible ayudar a construir un ser humano auténtico y verdadero.

Para A. Rocamora, si el ayudante no está bien o no es una persona sana, lo puede complicar todo. Para J. Barbero una tecnología humana puntera exige, por parte del ayudante, el reconocimiento de la dignidad de la persona y la importancia plena de la misma más allá de los protocolos, integrar bien humanización y tecnología, acogiendo sus preocupaciones y angustias desde una "relación basada en la libertad y en la participación activa de las partes". Finalmente J. Barbero nos recuerda que: "toda confrontación sin acogida previa se convierte en agresión"92.

Patterson cree que siempre hay una influencia, incluso de valores, sea o no pretendida, sea o no percibida, sea o no directiva, añadiría yo, si bien cada uno ha de vivirla desde su yo real y encuentra resistencias y obstáculos en sí mismo y en los otros. En este sentido, Rogers afirma que al principio la persona no reconoce sus problemas, ni acepta sus sentimientos. Pero poco a poco les va dando rienda suelta y es capaz de experimentar su vida, con todas sus consecuencias y con sus incongruencias, hasta que se hace libre y asume toda su responsabilidad.

Como dice M. Yela, la psicoterapia es un camino de libertad concreta, corporal y social, que va del "ego factum" al "ego faciens". Luego, en la vida de cada uno, hay que ir paso a paso de modo que podamos integrar bien nuestro ser en sí con nuestro ser con los otros, nuestra propia auto-

91 E. REPPETO, op. cit., p. 236.

92 J. BARBERo, “Humanización: ¿tecnología punta?”, en BermeJo J.C., (Ed.), Salir de la noche. Por una enfermería humanizada, 56. 
posesión, nuestra interiorización, con nuestra apertura y compromiso con los demás desde nuestro ser en libertad.

En conclusión, para E. Repetto, la relación de ayuda anima un proceso que va de la incongruencia a la congruencia e integración, mejora la confianza de la persona acerca de su propio ser y sus posibilidades, y desarrolla su libertad y su responsabilidad frente a la manipulación. Además, el counselling, propicia la experiencia de la riqueza de las relaciones humanas y su valor en la construcción del ser humano, anima a la experiencia de la propia empatía personal como camino de la construcción del yo actual y futuro en toda su plenitud.

Como resume Giordani, la destreza del terapeuta de atender físicamente, escuchar y observar, lleva a la implicación progresiva del ayudado; su responder al contenido, al sentimiento o a ambos, propicia la autoexploración de ayudado; personalizar el significado, el problema, el nuevo sentimiento y la meta, facilita el auto-conocimiento integrador del ayudado; y el iniciar para definir la meta, los pasos a dar y su refuerzo anima e invita a la persona ayudada a la acción y a definir un plan de acción. Siempre es necesaria una exploración mejor de la propia persona, una comprensión más profunda de uno mismo y una acción más efectiva. Pero esta es una tarea de toda la vida que hoy llamamos formación permanente en la que cada uno debe implicarse.

Finalmente, recordar que en el proceso de ayuda en Carkhuff, según Giordani, hay como tres momentos: Fase inicial o de auto-exploración, fase intermedia o de auto-comprensión y final o de acción. En cada una de estas fases las actitudes y habilidades han de usarse de diferente manera y de forma gradual. Así, en la fase inicial, el ayudante trabaja con cuatro disposiciones básicas: la empatía, el respeto, la concreción y la autenticidad, y las utiliza a nivel 3 o de respuesta intercambiable para no apabullar a la persona ayudada.

En la fase intermedia, se utiliza el nivel 4 y 5 de empatía y autenticidad, y se mantiene el nivel 4 del respeto. De manera más suave se usa la concreción, la confrontación, la relación al momento y la auto-revelación, aunque en el nivel 3, para no apurar al ayudado y "permitir la afluencia de contenidos inconscientes" o molestos. La fase final, se encamina hacia la acción en un clima de libertad, de autenticidad y convicción, y el ayudante aplica las 7 variables de Carkhuff "en los niveles más altos".

Aunque ya quedó dicho antes, no deja de llamar la atención que, al hablar del respeto en la fase final, Giordani resume la postura de Carkhuff con estas palabras : "Considerando el camino que se ha hecho, te acepto y te respeto sólo si te comprometes al máximo nivel que para ti es posible". 
Y, luego, cita un pasaje de Helping and Human Relations para insistir que se podría decir con Carkhuff: "el mensaje central de esta fase tiene que ver con la no aceptación del individuo que no esté dispuesto a comprometerse al grado máximo de sus posibilidades"93.

Así, vemos que Carkhuff, propone nuevas variables que, como la confrontación superan, bastante, la propuesta no directiva de Rogers. Además, valora de modo muy especial la persona del counsellor y su preparación, por la influencia que tiene en la relación de ayuda. Pero además, matiza la aceptación incondicional o actitud de respeto al ayudado de una forma muy importante, como acabamos de ver. Creo que no lo hace por capricho sino para tratar de evitar la falsificación de la propia relación de ayuda.

Y, de este modo, establece una nueva relación entre directividad y no directividad que Giordani describe como una especie de continuum entre ambas, con bastante respeto a las bases de Rogers, en mi modesta opinión. Así, como dice Alemany, Carkhuff tendría con Rogers una deuda importante, pero también un despegue de él que hace a Carkhuff diferente pues quiere ser más eficaz.

CONCLUSIÓN: LA NO DIRECTIVIDAD COMO CAMINO A LA AUTODIRECTIVIDAD. “Os conviene que yo me vaya" (Jn 16,7). "Rara temporum felicitate ubi sentire quae velis et que sentias dicere licet” (Tácito, Historiarum, liber I, 19-20).

En esta conclusión final, vamos a intentar recoger algunos elementos fundamentales que hemos ido elaborando, a lo largo de este trabajo, con respecto a la directividad y la no directividad en el acompañamiento personal, la relación de ayuda o el counselling.

En primer lugar, se puede afirmar con M. Buber, que lo que ayuda a cambiar a la persona no es la sabiduría ni el arte del terapeuta, ni su habilidad y experiencia práctica sino algo "completamente distinto", que está más allá de las técnicas, siempre necesarias y dignas de aprecio, o sea: la relación personal. Por eso mismo: "Van Kaam sostiene que la relación personal es el núcleo de la psicoterapia, la base del cambio y del desarrollo del cliente", según Repetto.

93 GioRdani, B., La relación de ayuda: De Rogers a Carkhuff, p. 266. 
Según Fiedler, toda terapia efectiva se caracteriza por la capacidad del terapeuta para comprender al otro "tal como éste se comprende a sí mismo". La técnica de la respuesta - reflejo no pretende sino "participar en la experiencia inmediata del cliente", sobre todo, a través "del reflejo del sentimiento o reflejo propiamente dicho", afirma Kinget.

Según Alejandro Rocamora, humanizar, hacer al hombre y hacernos más realmente humanos, consiste, precisamente, en pasar de una relación yo-eso (eso que es un enfermo, un alumno, un cliente o un delincuente) a una relación yo-tú, donde el tú es reconocido como una verdadera persona, con un yo propio y con voz propia, que nadie puede suplantar, como han mostrado M. Buber y E. Morin ${ }^{94}$.

De ahí, que el abismo del otro no sólo pide al terapeuta su seguridad de experto sino que le reclama "su propio abismo" y su misterio, esto es, la propia vida del asesor como persona, la identidad escondida bajo las estructuras del entrenamiento y las prácticas. Y esto es así porque, como sabemos muy bien, todo problema es siempre, en el fondo, un problema entre personas y de relación interpersonal, en el ámbito de la "entreidad", en una situación que se libra "entre uno y otro" y no un problema clínico que podemos encapsular y resolver en una sala de consulta.

De hecho Halkides, como recuerda Rogers, al investigar la eficacia de la terapia, sugiere que "ciertas actitudes y cualidades personales pueden bastar por sí mismas para asegurar el progreso independientemente de los conocimientos intelectuales o del entrenamiento médico o psicológico profesional"95.

O como lo dice Rogers, se requiere una relación "profundamente personal", no como un científico frente a un objeto ni un médico ante un diagnóstico, sino "como una persona hacia otra persona", portadora de "un valor intrínseco incondicional", y que el acompañante haya sido capaz de estar disponible para participar en la experiencia del acompañado y "confiar plenamente en la fuerzas de crecimiento que operan en el individuo, creando un clima propicio a "dejarlas libres" para "permitir al cliente ser él mismo".

Así, tendremos una persona "que ejerce libremente la plenitud de las potencialidades de su organismo", que vive la realidad, tiende al mantenimiento y realización de sí misma, que está integrada personal y socialmente de forma creativa, se descubre a sí misma siempre en la novedad de cada día,

\footnotetext{
94 A. Rocamora, “¿Qué entendemos por humanizar?”: Humanizar 82 (2005) 30-31.

95 C. Rogers - G. M. KINGET, op. cit. 314.
} 
y tiende siempre a actualizarse, a evolucionar y desarrollarse. Pues sabemos que: "donde abundó el pecado sobreabundó la gracia" (Rom 5,20).

Por eso, el buen counsellor nunca considera al otro un mero caso clínico sino como "una persona concreta", pues sabe que solamente podrá ayudarle a cambiar en la medida en la que él se deje afectar y transformar por él, sin querer dominarle ni situarse por encima del otro sino que ha de intentar adentrarse en el centro de su vida, para ayudarle, desde él mismo, en un intercambio que no es solamente de pensamientos y palabras sino principalmente de sentimientos y de experiencias vitales.

De este modo, el terapeuta vuelve a sus métodos propios, pero transformado por la experiencia, "como alguien a quien le ha sido revelada la necesidad de un auténtico encuentro personal en el abismo de la existencia humana entre uno que necesita ayuda y aquel que le ayuda"96.

Este encuentro personal, según Rogers, se caracteriza por la aceptación incondicional de la persona, para que pueda ser la que realmente es, y se parece mucho a lo M. Buber entiende por la relación "yo-tú". Así la persona aprende que es constructivo luchar por "encontrarse a sí mismo", entrar en la propia interioridad, aceptar los propios sentimientos, experimentarlos e integrarlos, sin miedo a la propia vida.

En ese encuentro, en el que se vive la experiencia del otro, desde dentro de él, aunque sin perder la propia identidad, los dos, ayudante y ayudado, quedan transformados. M. Buber cree que el ayudado viene a pedir ayuda porque lo necesita pero el terapeuta no. Pero Rogers replica: si pienso que "este que está ante mí es una persona enferma, entonces probablemente no voy a serle de tanta ayuda como podría ser. Lo que yo siento es que esa es una persona" 97 .

En lo que ambos autores están plenamente de acuerdo, es en que en el momento en que la persona ayudada puede experimentar auténticamente lo que el asesor expresa y experimenta, con su compresión y reacción, entonces se puede decir que "la terapia está casi terminada". Ese es el camino de vuelta a la vida, realmente, humanizada. Pues como dice Carkhuff: las dimensiones humanas que son efectivas en la vida normal "son efectivas en los procesos de orientación y terapia". Y eso es así, porque según Sullivan: "uno puede respetar a los otros sólo en la medida en que se respeta a sí mismo".

96 M. BubER, Sanación y Encuentro, Fundación E. Mounier, Madrid 2005, p. 16.

97 M. BubER, "Diálogo entre Martín Buber y Carl R. Rogers", en M. BuBER, op. cit. p. 23. 
Además, según Rogers, en la relación de ayuda se experimenta, con la persona ayudada, "una auténtica sensación de igualdad entre nosotros. Y me parece que éste es realmente, en cierto sentido, el fundamento de la ayuda". De ahí, que Rogers no mira a la persona ayudada como enfermo, ni siquiera en los casos más extremos, aunque sabe que eso no está bien visto en psicología y psiquiatría. Por eso, él cree: "que no hay diferencia entre la relación que establezco con una personal normal, y la que establezco con un esquizofrénico o con un paranoico. Realmente no siento ninguna diferencia". Y, para él, lo que hace a una terapia efectiva es que se trata de un "encuentro de personas".

Para Buber, el paranoico y el esquizofrénico son personas que están cerradas al otro. El hombre "normal", a veces, también se cierra. El problema es cómo conseguir "abrirse a sí mismo" y permanecer abierto. En cualquier caso, según Rogers, lo que importa es que estamos ante una persona que aunque esté tras una pantalla paranoica o con sus confusiones esquizofrénicas lo que nos interesa es saber: “¿Quién eres tú?”.

Así, cuando nos encontramos, como personas, entonces es cuando tiene lugar la ayuda y la transformación. Cuando yo veo a la persona tal como es, y él se da cuenta de mi comprensión y aceptación, el intercambio es recíproco y eso es lo que produce el cambio. M. Buber insiste en que Rogers le ha de proporcionar algo al ayudado que éste no tiene al comienzo del proceso.

Otro tema que quiere tratar Rogers es el encuentro consigo mismo, según M. Buber. En este tipo de encuentro la persona descubre algo que le inunda y le supera y que nunca había experimentado antes. Pero, es la persona la que ha de descubrirse a sí misma, y renacer a una vida nueva. Por eso, no hay otra directividad que la auto-directividad.

De ahí, que el fin de la relación de ayuda es que cada uno sea él mismo. Este es la clave de toda terapia. Como lo dice Schweitzer, para vernos libres del absurdo o del "sin sentido en que estamos prisioneros no tenemos otro camino que el que cada uno vuelva de nuevo a sí"(en sí). Sólo a partir de ahí podemos recuperar la capacidad de "creación de posibilidades", en palabras de Zubiri, para convertirnos en auténticas personas humanas.

Finalmente, Rogers insiste en que la naturaleza humana o la naturaleza básica del hombre es digna de "confianza, confiable". Según este punto de vista: "nadie necesita motivación suplementaria para orientarse hacia.lo positivo o hacia lo constructivo. Está ya en el individuo. En otras palabras: si podemos liberar lo que es más fundamental en el individuo, esto será constructivo"98.

98 M. BuBER, Ibid., p. 32. 
M. Buber no está, totalmente, de acuerdo en esto. Él piensa que la realidad humana es polar, especialmente cuando las personas tienen un problema, pero nosotros podemos ayudar a cambiar la relación entre los dos polos para que sea el polo bueno el que oriente y dirija la vida de la persona y fortalezca su "sí" a la vida.

También se plantea, en este diálogo, si la experiencia de respeto y aceptación cálida y segura de la persona, en la teoría de Rogers, es similar a la experiencia de confirmación en Buber. Para éste aceptar a la persona es hacerle sentir que la acepto tal y como es. Pero confirmar, según Buber, "es aceptar toda la potencialidad del otro e, incluso, diferenciar sus diversas capacidades", al aceptarle, amorosamente, lo que está llamado a ser. En este sentido, Rogers, está básicamente de acuerdo, si bien cree que "se propicia el cambio y se libera todo el potencial personal al descubrir que siendo como soy, exactamente como soy, soy totalmente aceptado".

Buber cree que hay que introducir la idea de redención y de esperanza porque cuando la persona se encuentra en una situación problemática, sin suelo firme, sin punto de apoyo, solamente a partir de la idea de que el hombre puede ser redimido y que tiene una esperanza es posible ayudar a la persona para ir hacia adelante. Pero esto, según Buber, "puedo hacerlo solamente distinguiendo entre 'aceptación' y 'confirmación"”.

En relación con este tema de la esperanza y el cambio conviene recordar que, según los estudios de M. J. Lambert, adaptados por J. J. Murphy, la esperanza se lleva un $15 \%$ de influencia en los procesos de cambio, el mismo porcentaje que se atribuye al uso de unas buenas técnicas bien asimiladas ${ }^{99}$.

Para Buber, confirmar a una persona, tal como ella es ahora, es sólo un primer paso que busca desarrollar toda su potencialidad en lo que puede llegar a ser. Por lo demás, el encuentro existencial de ayuda es una alianza terapéutica de amistad que intenta "traer al paciente a su autocuración" para que llegue a dar de sí lo mejor de sí mismo, lo más sustancial de su persona. Rogers cree que la discusión sería interminable y que es necesario ponerle fin.

99 M. Costa Cabanillas, E. LóPez MÉndez, Consejo psicológico. Una alianza estratégica para el apoyo, la potenciación y el cambio, Síntesis, Madrid 2003, pp. 127-8: Según Murphy, los factores que mejoran el resultado del consejo se distribuyen así:

"1. Factores del cliente (40\%): fuerzas personales, recursos, creencias, apoyos sociales.

2. Factores de relación (30\%): empatía, aceptación, calidez de la relación.

3. Factores de expectativa (15\%): esperanza y expectativas de cambio.

4. Factores técnicos y de modelo (15\%): orientación técnica y técnicas de intervención utilizadas". 
Entonces el moderador del coloquio, M. Friedman, les hace una pregunta final a los dos, que se basa en su impresión de que Rogers está más centrado en el cliente pero da suma importancia a la relación yo-tú, mientras que Buber se apoya menos en la reciprocidad o igualdad entre ayudante y ayudado pero da mucha más importancia a la relación "entre", y les pregunta cuál es, realmente, la diferencia entre ambos.

Rogers cree que se trata de aceptar profundamente el proceso en el que estamos "de llegar a ser lo se que es". Buber piensa que sería bueno distinguir entre individuo y persona. El individuo puede llegar a ser muy suyo y muy singular sin llegar a hacerse persona. Pues uno se hace persona, en el mundo y con los otros, "sólo en contacto auténtico, en reciprocidad real con el mundo bajo todos los sentidos en los cuales el hombre se puede encontrar en el mundo"100.

Según Buber, incluso el esquizofrénico, busca compartir un hogar común humano con los otros, aunque él crea que el suyo es el verdadero. Y el mismo Buber insiste en que: "La realidad decisiva es el terapeuta, no los métodos". $\mathrm{Y}$, por tanto, llegado un momento clave, se debe renunciar a las tipologías y al método para entrar en la relación única entre ayudante y ayudado.

Estamos ante una cooperación entre dos personas en la cual "el terapeuta es solamente una especie de comadrona". Y esto es así porque, según Buber: "La persona no existe antes de tener un ser personal como compañero, antes de vivir en contraste con él, orientado hacia él, y que sea significativo antes de que haya tratado con él". Y, porque: "el misterio del llegar-a-ser del lenguaje y el de llegar-a-ser del hombre son uno".

Todo eso supone una cierta cercanía y alguna distancia en la que la verdad de la vida y del ser humano perdura siempre y se hace interpersonal, aquí y ahora, en busca de plenitud. Así, la relación humana de ayuda cumple "su auténtica tarea, que es la regeneración del núcleo personal bloqueado". Y esto sólo puede hacerse "en una relación persona-a-persona" que promueva la liberación y actualización de la plena integración humana reconciliada con el mundo.

Este tipo de psicólogo, en el que se impone la buena voluntad, como en Sullivan, que "está preparado para recibir lo que sea", y no impone su método, es en el que cree Buber. En este sentido, "su auténtico trabajo es cuestión de obediencia escuchante". En efecto, el terapeuta vulgar se impone al paciente sin darse cuenta. Por tanto, es preciso liberar al "paciente de la imposición inconsciente del terapeuta, dejando al paciente a sí mismo".

100 M. BubER, “Diálogo entre Martín Buber y Carl R. Rogers”, p. 37. 
El terapeuta se acerca, con delicadeza, al paciente, "pero debe intentar influir en él lo menos posible", sobre todo, debe evitar hacerlo con ideas generales. Así, estamos ante una relación dialógica que es: "Relación y reciprocidad. Mi 'tú' actúa sobre mi Yo como Yo sobre él. Nuestros alumnos nos forman, nuestra obras nos edifican (Buber)"101. Son las propias cualidades innatas de la persona para la "auto-curación" las que funcionan. Es la tendencia intrínseca del "organismo a desarrollar todas sus capacidades" la que se impone y rige el proceso de cambio.

De hecho, cuando el ayudante no confía en el ayudado, el cambio se hace imposible. $\mathrm{Y}$ eso, es así porque en la terapia, la persona ayudada debe ser dejada a sí misma "con la humildad del maestro". Luego, el asesor "espera lo inesperado y no lo clasifica en categorías". Según Buber, es mucho más fácil imponer el propio esquema que "usar toda la fuerza del alma para dejarle a sí mismo y no tocarle, por así decir"(...) "Si juzgas a Eliot por Keats puedes fallar. El verdadero maestro responde a la singularidad"102.

El ayudante, debe saber también que no puede conducir a la persona al mundo real ni siquiera mostrarle el camino. Como mucho, puede ayudarle a acercarse al punto desde el que pueda divisarlo, pero "ha de ser el paciente quien busque y encuentre su propia ley personal". En este proceso de cambio el ser humano personal no puede ser sustituido. Sólo la propia conciencia, el abismo del 'yo-conmigo' puede redimirse, con toda su alma, corazón y vida, en la intimidad de su ser, en una 'perseverante auto-identificación' y en una renovada reconciliación con el mundo.

Pues, sólo el propio ser humano puede asumir la responsabilidad de elevarse a su mejor nivel e iluminar, humildemente, su proceso de cambio, recobrar su verdad, su autenticidad, su inocencia y su propia identidad reconciliada y renacida de su 'self', su yo.

Solamente así, la confrontación consigo mismo, "en el ámbito esencial del pasado" y en el "caos de posibilidades de ser" del presente, puede llevar a la persona a hacerse un hombre nuevo, integrado y unificado, en el que el caos se vuelve cosmos y todo recupera el sentido. Entonces la persona se convierte en una aventura vital, y se hace su propio creador, pues: "Uno es lo que quiere y quiere ser lo que es".

De este modo, el hombre se elige a sí mismo y da un sí grande a su propia vida en su mundo, que es un sí a toda persona humana, que nada ni

101 J. Segura, “Carl Rogers", op. cit., p. 103.
102 M. Buber, op. cit., p. 51. 
nadie podrá romper, y en el que el hombre se revela a sí mismo en su identidad y autenticidad más plena.

Las observaciones de Buber y Rogers, recogidas en los párrafos anteriores, creo que resumen muy bien el sentido de lo que debemos entender por una no directividad sana y auténtica y, por tanto, verdadera, que puede concretarse así:

$1^{\circ}$.- Lo que conduce al cambio no son tanto las técnicas o habilidad del ayudante como la misma relación interpersonal, y su parte sana que llama a la parte sana del ayudado.

$2^{\circ}$.- Esta relación interpersonal supone la aceptación incondicional de la persona, en el lenguaje de Rogers, y desarrollar una relación yo-tú, según M. Buber, en la que no hay superior ni inferior, dominante ni dominado.

$3^{\circ}$.- Según Rogers, se trata de una relación de igualdad en la que no se mira al otro como enfermo, aunque venga a pedir ayuda, porque se encuentra en un estado esquizofrénico o paranoico, pues, por encima de todo, es una persona humana.

$4^{\circ}$.- Además, según Rogers, esto supone creer plenamente en la capacidad de la persona ayudada para cambiar su situación y desarrollar todas sus potencialidades. Mientras, para Buber, conviene distinguir entre aceptar, incondicionalmente, y confirmar, que supone generar una esperanza en lo que la persona puede llegar a ser y no sólo en lo que es. En ese sentido, según Buber, al ayudado se le ofrece algo que no tiene, pues siempre hay un plus en la vida humana que nos sobrecoge y no es posible controlar.

$5^{\circ}$.- Pero Rogers insiste en que la naturaleza humana es fiable, digna de confianza en sí misma, no necesita una motivación suplementaria para mejorar. $\mathrm{Y}$ el pesimismo basado en las religiones o en otras creencias no tiene sentido alguno ni responde a la verdad del ser humano en cuanto tal. Por eso, el ayudante es una comadrona que ayuda a dar a luz lo que la persona ayudada ha engendrado y creado y desea cultivar.

Por eso, de una forma más concreta, creo que es posible afirmar, con respecto al tema que nos ha ocupado, a lo largo de este estudio, que:

5.1‥- La verdadera tarea de la relación de ayuda es "la regeneración del núcleo personal bloqueado" y la liberación y actualización de la plena integración humana de la persona ayudada y su mundo desde su propia autonomía (J. Barbero y Pilar Barreto, R. Bodei).

$5.2^{\circ}$.- En este sentido, el ayudante "está preparado para recibir lo que sea", y "su auténtico trabajo es cuestión de obediencia escuchante", confia- 
do en que en toda crisis o "ruptura de esperanza" hay una oportunidad feliz de reconstrucción de la persona, y de ayudarle a ser "más auténtica, a tener la libertad de ser ella misma".

5.3․- De ahí, que el terapeuta vulgar "se impone al paciente sin ser consciente de ello", pero el verdadero asesor "debe intentar influir en él lo menos posible". Cuando el ayudante no confía en el ayudado, el cambio se hace imposible.

$5.4^{\circ}$.- Y, eso es así, porque, en la relación de ayuda, la persona ayudada debe ser dejada a sí misma "con la humildad del maestro". Luego el asesor "espera lo inesperado", sin clasificarlo ni encajonarlo nunca en sus categorías.

5.5 .- El ayudante debe usar "toda la fuerza de su alma para dejarle a sí mismo (al ayudado) y no tocarle, por así decir". Tampoco puede ni debe señalarle el camino. Es la persona ayudada la que ha de encontrar su camino, su propia ley y su ruta de identidad.

Por eso, la terapia centrada en el cliente es una terapia "auto-directiva", del individuo o del grupo, en la que cada uno experimenta que: "puedo ser yo mismo, sin simulaciones", pues se le respeta "tal como es", "capaz para crecer y auto-dirigirse".

En este proceso, la persona hace una auto-comprensión propia con su material más profundo, una verdadera reorganización vital y "una integración más realista" con conductas más agradables, más apropiadas y adecuadas.

Y, en definitiva, como dice Rogers:

"La tarea del especialista no consiste en valorar la conductas, las necesidades y metas, en una palabra, la personalidad de los demás, sino en crear condiciones en las que la capacidad de autodeterminación del ser humano pueda actualizarse, tanto en el plano social como en el individual. La competencia específica del profesional de las relaciones humanas consistiría en facilitar el desarrollo autónomo del individuo ${ }^{103}$.

\author{
Domingo Natal Álvarez \\ Estudio Teológico Agustiniano \\ Valladolid
}

103 C. Rogers, - G. MARIAN KINGET, op. cit., IIº, 274. Remarcado mío. 